\title{
1876 İstanbul Konferansı'na Sunulan Doğu ve Batı Bulgaristan Vilayetleri Önerisi *
}

\author{
Sevim HACIOĞLU **
}

\begin{abstract}
$\ddot{O} z$
1876 İstanbul Konferansı, Avrupa Güçlerinin diplomatik hamlelerindeki değişimi, Osmanlı Devleti’nin iç sorunlarına çözüm arayışını ve günümüz Balkan ülkelerinin tarih sahnesine çıkış sürecini incelemede önemlidir. Bu makalede Konferans bağlamındaki inceleme, Osmanlı Devleti’nin Rumeli topraklarında Doğu ve Batı Bulgaristan Vilayetleri kurulması tartışmasıyla sinırlı tutuldu. Çalışmamızda önce konuyla ilgili bilgi aktaran Bulgarca, Rusça ve Türkçe kaynaklardan tarih yazımı örneklerine yer verildi. Bir kaynakta anılan toplantıda bazı kararların alındığı yönünde anlaşılacak ifadeler geçmekteydi. Bir diğer kaynağa göre 1870’teki kuruluşu esnasında Bulgar Eksarhlı̆̆ı’nın yetki alanı olarak belirlenen bölgenin sınırları, 1876 İstanbul Konferansı görüşmelerinde Avrupalı sefirlerce modern Bulgar ulusunun ülke sınırları olarak onaylanmıştı. Bir kaynakta ise Konferans’ta önerilen idari taksimata itiraz etmekle Osmanlı Devleti’nin, Bulgar ulusunun mevcudiyetini inkâr etmiş olduğu belirtilmekteydi.
\end{abstract}

Makalenin devamında bu kaynaklardaki ifadelerin gerçeğe uygunluğu, bu hususta birincil kaynak olan Konferans tutanaklarından yola çıkılarak incelendi. Araştırmamızda 1876 Tersane Konferansı'nda herhangi bir kararın alınmadığı ve bağlayıcı bir neticeye ulaşılmadığı teyit edildi. Ayrıca kimi kaynaklarda belirtilenin aksine, Osmanlı Devleti’nin Konferans'ta önerilen ıslahata itirazının, kendi toprak bütünlüğü ve güvenliğini korumaya odaklı olduğu izah edilmeye çalışıldı.

Anahtar Sözcükler: Tersane Konferans1, 1876 İstanbul Konferansı, Bulgar meselesi, Doğu ve Batı Bulgaristan Vilayetleri.

\section{The Project of Eastern and Western Bulgaria Vilayets Presented to the 1876 Constantinople Conference}

\begin{abstract}
The 1876-1877 Constantinople Conference is important in the pursue of the European Powers diplomatic moves' variation, also of the Ottoman Empire's search for solutions to its internal problems and of the historical process which established todays national states in the Balkans. This article focuses on this Conference by limiting its research topic with the discussion regarding the proposed
\end{abstract}

\footnotetext{
*- Bu makale yazarın, 2009 yılında İstanbul Üniversitesi Sosyal Bilimler Enstitüsü Tarih Anabilim Dalı'nda Prof. Dr. Halil Bal'ın danışmanlığında tamamladığı "Bulgaristan Sınırlarının Oluşumu ve Bu Sürecin Türkiye'ye Etkisi (1876-1919)" adlı yayınlanmamış Doktora tezinin birinci bölümünden yola çıkılarak hazırlanmıştır. Adı geçen tez İstanbul Üniversitesi Bilimsel Araştırma Projeleri Komisyonunca desteklenmiştir, Proje No: T-702/30062005.

**- Dr. Öğr. Üyesi, Kırklareli Üniversitesi Fen Edebiyat Fakültesi Sosyoloji Bölümü, 39000, Kırklareli/Türkiye. ORCID: 0000-0002-1386-8437. e-posta: hacioglu.sevim@klu.edu.tr.
} 
new administrative division of Ottoman Rumelia: the Eastern and Western Bulgaria Vilayets.

With this purpose first, some historiographical texts in Bulgarian, Russian and Turkish were quoted. According to some expressions in these texts, the Conference reached some diplomatic decisions or conclusions. Some other expressions were implying that the borders of the region recognized in 1870 by the Ottoman Empire to be the Bulgarian Exarchate's responsibility area, were approved by the European ambassadors at the 1876 Constantinople Conference being the territorial borders of the modern Bulgarian national state. According to some other expressions, by rejecting the proposal for the new administrative division in Rumelia the Ottoman Empire was denying the existence of the Bulgarian nation.

In the following part of the article its topic was examined according to the Conference Protocols. As a result, it was confirmed that at the mentioned Conference no decisions or conclusions were reached. Also, it was stated that the rejection of the establishment of two new Bulgaria Vilayets in Rumelia was important for the Ottoman Empire in saving its territorial integrity and assuring its security.

Key Words: 1876-77 Constantinople Conference, Eastern Question, East and West Bulgaria Vilayets.

\section{GíRIŞ}

1876 İstanbul Konferansı, 23 Aralık 1876 - 20 Ocak 1877 tarihleri arasında, Osmanlı Devleti ile Almanya, Avusturya-Macaristan, Fransa, İngiltere, İtalya ve Rusya’nın katılımıyla gerçekleşmiştir. Bağlayıcı bir neticeye ulaşmamış olmasıyla Konferansın nispeten gölgede kaldığı ve 23 Aralık 1876 gününün, Osmanlı tarihinde daha ziyade Kanun-1 Esasi’nin ilanıyla anıldığı söylenebilir.

Öte yandan bu toplantı, uluslararası diplomasi tarihi bağlamında Avrupa Güçlerinin, Osmanlı Devleti’nin Rumeli eyaletleri konulu düşüncelerini, kullandıkları söylemi ve diplomatik hamlelerindeki değişimi incelemede önem arz eder. Bundan başka, Osmanlı Devleti’nin iç sorunlarına çözüm arayışını ve toprak bütünlügüüü koruma gayretiyle takip ettiği siyaseti izlemede mühimdir. Üçüncü olarak, günümüz Balkan ülkelerinin tarih sahnesine ulusal devletler olarak çıkış süreçlerini anlamada yardımcıdır.

Soğuk Savaşın ardından Avrupa’da güncellenmesi gereği duyulan tarih yazımı, ister istemez Osmanlı Devleti tarihi konulu eserleri de kapsamaktadır. Yabancı ayrıca ülkemiz eserlerinde, 1876 İstanbul Konferansı özelinde geçen bazı ifadeler dolayısıyla, geçmişte vuku bulanların aslından farklı anlaşılması ihtimali söz konusudur. Tarih bilgilerini teyit ihtiyacının doğduğu böyle durumlarda izlenebilecek yol, konuyla ilgili birincil kaynakları yeniden inceleyerek güvenilir bilgiye ulaşmaya çalışmaktır.

Bu makalenin konusu 1876 İstanbul Konferansı'nın müzakereleri ve nasıl neticelendiğidir. Konferans'ta birden fazla mesele görüşüldüğünden incelememiz, Osmanlı Devleti Rumeli topraklarında Doğu ve Batı Bulgaristan Vilayetleri kurulması önerisi etrafındaki tartışmalarla sınırlı tutuldu. 
Araştırmamızda önce Konferans'la ilgili bazı tarih yazımı örnekleri ele alındı. Söz konusu örnekler Rus, Bulgar ve Türk kaynaklarından seçildi. Anılan toplantı ve iki Bulgaristan Vilayeti kurulması bağlamında bu kaynaklarda kaydedilenler kısaca aktarıldıktan sonra mevzu, Başbakanlık Osmanlı Arşivleri’nde bulunan Konferans tutanaklarından yola çıkılarak irdelendi. Böylece Aralık 1876 - Ocak 1877 İstanbul Konferansı'nda gerçekte tecrübe edilenler ile bu konuda sonradan yazılanları karşılaştırarak nesnel değerlendirme yapabilecek veri elde edildi.

\section{1876 İSTANBUL KONFERANSI KONULU TARİH YAZIMI ÖRNEKLERİ}

\subsection{Ansiklopedilerden İki Örnek}

Konumuz olan toplantı, Rusya'nın temel başvuru eserlerinden Entsiklopedicheskiy Slovar' Brokgauza i Efrona'nın "Konstantinopol'skaya Konferentsiya" maddesinde, İngiltere'nin teklifiyle, Aralık 1876'da İstanbul'da düzenlenen "Büyük Devletlerin Konferansı" olarak anılmıştır. Buradaki bilgiye göre Konferansın tertiplenme amacı, Bosna-Hersek’teki isyana, Bulgaristan'daki asayişsizliğe ve Osmanlı Devleti’nin Sırp ve Karadağlılarla muharebesi sonrasında oluşan müşkül duruma çözüm bulunmasıydı. Anılan meseleler konusunda Avrupa Devletleri arasındaki “...keskin...” fikir ayrılı̆̆ının Konferans esnasında açığa çıkmaması ve Osmanlı temsilcileri nezdinde münakaşaya girmemeleri amacıyla Avrupa sefirleri, Rusya’nın ısrarı üzerine, uzlaşacakları ön görüşmelerde bulunmuştu. 11-22 Aralık 1876 tarihleri arasında, İstanbul Rus Konsolosluğu binasında General İgnatiyev'in ev sahipliğinde yapılan dokuz ön görüşmede özellikle İngiltere ile Rusya arasındaki fikir ayrılı̆̆ 1 giderilmeye çalışılmıştı. Netice olarak, Avrupa Devletleri’nin Babıali'ye sunacakları müşterek bir “...talepler programı...” hazırlanmıştı.

Maddenin devamında bu taleplere yer verilmiştir: Osmanlı Devleti’nce Karadağ ve Sırbistan'a dâhil edilmesi istenen bölgeler belirtilmiş, Bosna, Hersek ve Bulgaristan'da (buna Makedonya da dâhil edilerek) üç ay zarfında otonomi ve mahalli idareler kurulması ve bunların idari düzenleri bağlamında vali, meclis, vergi vd. ayrıntılara değinilmiştir. Devamdaki bilgiye göre Konferansın 23 Aralık 1876'daki ilk oturumunda Osmanlı temsilcilerine sunulan bu talepler, görüşmelerin sekiz oturum sürmesine ve 20 Ocak 1877'de verilen ültimatoma rağmen, Osmanlı Hükûmetince reddedilmişti. Bu netice Henry Elliot ile Lord Derby'nin Osmanlı devlet ricaline telkinlerinin eseriydi ki Rusya ile olası bir savaş koşulunda Osmanlılar, İngiltere ile Avusturya-Macaristan'dan destek bulmayı beklemekteydi (Entsiklopedicheskiy, 1895: 59-60). Öte yandan bu metinde, Rumelide kurulması önerilen Doğu ve Batı Bulgaristan Vilayetleri ve kapsayacakları bölgeler konusunda ayrıntılar aktarılmamıştır.

Bulgaristan’ı 1989 öncesi temel başvuru eserlerinden Kratka Balgarska Entsiklopediya’nın “Tsarigradska Konferentsiya 1876-1877" adlı maddesine göre Konferans, Bosna ve Hersek’teki isyan ayrıca, Nisan 1876'daki Bulgar isyanı sonrasında Rusya'nın ısrarıyla 
Aralık 1876'da, Avrupa Büyük Devletleri ve Osmanlı Devleti’nin katılımıyla gerçekleşmişti. Toplantının amacı Balkanlar'da Osmanlı idaresinde yaşayan Hristiyanların durumunu görüşmek ve Bulgar meselesine “...radikal...” (nihai) bir çözüm bulmaktı. General İgnatiyev'in teşebbüsüyle 11-22 Aralık 1876 tarihlerinde yapılan (ve bu metinde kimlerin katılımıyla olduğu belirtilmeyen) ön görüşmelerde, Bulgar Eksarhlığı sınırları dâhilinde yani, “...Kuzey Bulgaristan’, Trakya’nın bir kısmını ve tüm Makedonya’yı kapsayacak, Tırnova merkezli Doğu ve Sofya merkezli Batı bölgelerinden müteşekkil, bir Bulgar otonom bölgenin kurulması yönünde oybirliğiyle karar verilmişti”. Benzer bir reform Bosna ve Hersek için de düşünülmüş, Konferans'ta Osmanlı Devleti ile Sırbistan ve Karadağ arasında uzlaşı şartları da mevzu edilmişti.

Maddenin devamında mahalli idare konulu tavsiyelere değinilerek “...projeye göre anılan iki bölgeye, Bulgar asıllı nüfusun çoğunlukta olduğu Rodop dağları sahasının büyük kısmı ile Batı ve Doğu Trakya dâhil edilmeyerek, Bulgaristan’’n Ege Denizine çıkışının engellendiği...” kaydedilmiştir. Ardından, (ön görüşmelerde) projeyi onayladığı halde İngiltere'nin Konferans oturumları esnasında, Avrupa Devletleri’nin önerilerini sekteye uğratmak üzere, Osmanlı Devleti’ni destekleyici gizli lobicilik yaptığı; öte yandan zaman kazanmak amacıyla Osmanlı temsilcilerinin Avrupa Devletleri’nin önerilerini reddederek tali konularda tartışmalara girdikleri hatta Bulgar ulusunun varlığını inkâr edecek derecede ileri gittiklerine değinilmiştir. Metne göre Osmanlı Devleti Bulgaristan'a otonomi verilmesine razı olmamış, (Konferans bitimine yakın) toplanan Şûra da Avrupa Devletleri'nin önerilerini reddetmişti. Neticede Konferans bir karar almamıştı. Ancak Konferansın toplanması, “...Bulgar milli meselesinin, tüm Avrupa Devletleri temsilcilerince tanınmasında büyük önem taşıyordu” (Kratka Balgarska, 1969: 409).

\subsection{Mir'ât'ı Hakîkat'ten Birkaç Alıntı}

Dönemin ve Konferans görüşmelerinin tanığı, Osmanlı devlet adamı Mahmud Celâleddin Paşa’nın (1838-1899) kaleme aldığı Mirât-ı Hakîkat eserinde, konumuz özelinde yanlış algılanabilecek ifadelere rastlıyoruz. Aşağıda üzerinde durulan kelime ve ifadeler, kitabın Osmanlıca metnindeki asıllarıyla büyük ölçüde örtüşmektedir (Celâleddin Paşa, 1326: 225-226, 230 vd.). Öte yandan günümüzde Miroğlu tarafından sadeleştirilen metne daha çok başvurulduğundan, alıntılar 1983'te neşredilen Mirầt-ı Hakîkat eserinden aktarıldı.

Kitabın 1. Cilt, 3. Bölüm, 7. Faslının başlığı "Konferansın toplanması - konferansta alınan kararların özeti ve konferansta ileri sürülen tekliflerin reddedilmesi” şeklinde düzenlenmiştir. Başlıktaki sıralamadan Konferansın toplandığı, birtakım kararlar aldığı, bunun ardından sunulan birtakım tekliflerin reddedildiği anlaşılmaktadır. Başlığı ilk kez okuyan günümüz okurunun, Konferansın akışında bir sıradışılık sezmesi olasıdır. Nitekim halen yaygın uygulamaya göre bu tür toplantılarda, alınan kararlar konuşma veya görüşmelerde varılan neticeyi teşkil etmekte ve ilgili taraf, muhatap ya da kamuya "sonuç" sıfatıyla duyurulmaktadır. Dolayısıyla andığımız başlığın düzenleniş biçimi, Konferans gündeminin (tekliflerin sunulması; görüşülmesi ve onaylanması ya da reddedilmesinin), ulaşılan neticeden (alınan kararlardan) sonra devam ettiği izlenimini edindirmektedir. 
Öte yandan metnin devamında "karar" kelimesi birkaç farklı manada kullanılmıştır. Bunları örnekleyecek olursak:

1- “...İngiltere ve Fransa temsilcilerinin, konferansta Osmanlı Devleti’ne faydalı bir karar alınmasına çalışacaklarına büyük bir ümit beslenmekte idi” ve “...bu konferansın toplanmasına ...muvâfakat olunmuş olmakla beraber, burada alınacak kararların, Osmanlı Devleti'ne zarardan başka bir şey veremiyeceği düşüncesine dayanılarak...” (Celâleddin Paşa, 1983: 206) cümlelerinde "karar" kelimesi, konferansın ulaşacağı netice manasını ifade etmektedir.

2- "Devletlerin temsilcileri ise, zâten Osmanlı Devleti'nin arzusuna uygun olmıyan müşterek tasavvurlarını, ...önce, Rus sefâretinde ve Osmanlı Devleti temsilcilerinin gıyabında meramlarını istedikleri gibi tesbit ettikden sonra konferansa tam anlaşmış olarak girdiler ve aralarında kararlaştırılmış olan teklif ve kararları ortaya koydular" (Celâleddin Paşa, 1983: 207) cümlesinde ise varılan uzlaşı, fikir birliği manasında kullanılmıştır. Söz konusu uzlaşı, Konferansa katılan tüm taraflar arasında değil; Osmanlı temsilcilerinin gıyabında, yalnızca Avrupalı sefirlerin arasında sağlanmıştır.

Öte yandan bu cümlede "karar" kelimesi, "teklif” kelimesiyle yan yanadır. Okurun burada aklına gelebilecek, anılan iki kelimenin yakın anlamda kullanılıp kullanılmadığı sorusunun yanıtını, devamdaki satırlarda buluyoruz:

3- "Nihâyet temsilciler, konferansta alınacak kararları birbirinden ayırarak, Bosna, Hersek, Sırbistan ve Karadağ meseleleri hakkında ayrı ayrı projeler ileri sürdükleri gibi, Bulgaristan'ı iki vilâyete bölerek, bunun idâresine dâir bir proje de hazırladılar ve tekliflerini geçici ve devamlı olmak üzere iki kısma ayırdılar" (Celâleddin Paşa, 1983: 208) cümlesinde "alınacak kararlar" ifadesi Konferans'ta görüşülecek konular manasına gelmekte olup bunlar, "proje” ve "teklif” kelimeleriyle bağdaştırılmıştır. Bu bağdaştırma dolayısıyla yukarıdaki alıntıda "karar" ile "teklif" kelimelerinin yalnızca yan yana değil, eș anlamda kullanıldığı anlaşılmaktadır. Dolayısıyla "karar” sözcüğü burada, Avrupa temsilcilerinin uzlaşarak oluşturdukları tavsiye (taslak, öneri, proje) yani, teklifleri işaret eder manadadır. Böylece bu satırlara geldiğinde okurun anlayacağı, İstanbul Konferansı başlamadan evvel aralarında istişare eden Avrupa temsilcilerinin birtakım öneriler tespit ettikleridir.

Dolayısıyla yukarıdaki 2. ve 3. alıntılarda, Avrupalı sefirlerin kendi aralarında uzlaşarak oluşturdukları önerileri (projeleri) Osmanlı Devleti’ne takdim ettikleri ve ilk oturumunu takiben 1876 İstanbul Konferansı'nda gündemin, bu projeleri görüşmekten ibaret olduğu anlatılmaktaydı. Bu sebeple, Faslın başlığındaki "konferansta alınan kararların özeti” ifadesinin, "Devletlerin temsilcileri... konferansa tam anlaşmış olarak girdiler ve aralarında kararlaştırılmış olan teklif ve kararları ortaya koydular” cümlesindeki bağlamda anlaşılması gerektiği ortaya çıkmaktadır.

Anlamca zıt olan "teklif” ile "karar” kelimelerini bu eserde eş anlamda kullanılmış olması 
ilk bakışta yadırganabilmektedir. Ancak Faslın başlı̆̆ını düzenleme biçimi ve "karar" sözcügüün birkaç manada kullanılması sebebiyle okurun algılayacağı karışıklık, metnin devamında yerli yerine oturmaktadır. Nitekim takip eden "Sırbistan meselesi ile ilgili karar", "Karadağ meselesi ile ilgili karar", "Bosna-Hersek ve Bulgaristan için kararlaştırılan idâre tarzları" (Celâleddin Paşa, 1983: 208-209) adlı kısımlarda adı geçen bölgeler bağlamında, Avrupalı sefirlerin uzlaşarak oluşturdukları 1slahat önerileri aktarılmıştır. Aşağıda değinileceği gibi Osmanlı Devleti’ne resmen sunulan Fransızca metinlerde bunlar "Projet" (Tr.: "proje”) olarak adlandırılmıştı.

Öte yandan kitabın devamındaki sayfalarında az evvel "karar" kelimesiyle işaret edilen öneriler, bu kez "haksız ve zararlı teklifler" ayrıca "şartlar" olarak anılmıştır: 1- "Fakat konferansta ileri sürülen haksız ve zararl teklifleri kabul etmekten ve haysiyeti zedeleyen bir duruma katlanmaktansa savaşı kabul etmek devlet ve milletin şânına daha çok yakışır”. 2- "Bulgaristan’n o kadar büyük imtiyâzlı bir ülke hâline getirilmesinin, vâlilerinin hıristiyanlardan tâyin edilmesinin ve teşkilâtlandırılması ile ilgili daha başka şartların... neticede, oralardan... Osmanlı hâkimiyetinin kaldırılmasına yol açacağı...” (Celâleddin Paşa, 1983: 218, 212).

Netice olarak Mir'ât-ı Hakîkat eserinde "karar" kelimesinin Konferans müzakereleri yoluyla varılmış bir neticeyi ifade etmediği, oturumlarında görüşülmek üzere ayrı konular halinde düzenlenmiş 1slahat tavsiyelerine işaret ettiğini anlıyoruz. Nitekim eserde Konferansın bir neticeye ulaşmaksızın, sefirlerin İstanbul'dan ayrılmasıyla son bulduğu belirtilmektedir (Celâleddin Paşa, 1983: 220).

\subsection{Bir Yakın Dönem Kaynağından Örnek}

1876 İstanbul Konferansı esnasında Avrupa sefirlerince Osmanlı Devleti'ne takdim edilen 1slahat tavsiyeleri 1895 tarihli Entsiklopedicheskiy Slovar' kaynağına göre sefirlerin uzlaşısıyla oluşturulmuş bir "talepler programı" idi. Bu talepler, Osmanlı Hükûmetince reddedilmişti. Konferansta bir karar alınmamış, neticeye varılmamıştı.

1969 tarihli Kratka Balgarska Entsiklopediya kaynağına göre bunlar Osmanlı Devleti’ne sunulan bir "projeydi" öte yandan, ansiklopedi metninde anılan coğrafyada bir "Bulgar otonom bölgesinin" kurulması yönünde oybirliğiyle alınmış bir kararı yansıtmaktaydı. $\mathrm{Bu}$ karar, İgnatiyev'in girişimiyle yapılan ön görüşmelerde alınmıştı. Öte yandan ön görüşmelere yalnızca Avrupa sefirlerinin katıldığı vurgulanmadığı halde bu husus, devamdaki satırlarda Osmanlı Devleti’nin ilgili öneriyi reddettiği bilgisiyle teyit olmaktadır. Nitekim bu kaynakta da Konferansın bir karar alınmadan ve neticeye ulaşmadan sona erdiği belirtilmektedir.

Üniversite öğrencilerine yönelik ders gereci olan Istoriya na Balgariya eserinde neşredilen iki makalede, farklı hatta karmaşık bir bilgiyle karşılaşıyoruz. Burada önce "İstanbul Sefirler Konferansı” olarak anılan toplantıda “...delegelerin 11 Aralık 1876'da başlayan ön görüşmelerinde ...oldukça gergin konuşma ve diplomatik müzakereleri takiben ... 
bağımsız Bulgar Kilisesi Fermanında (Bulgar Eksarhlığı’nın kuruluşu Fermanında) belirtilmiş olan yaklaşık aynı sınırlar dâhilinde, Bulgarlara otonomi verilmesi kararına...” varıldığ 1 ifade edilmiştir. İngiltere sefiri Salisbury’nin “....ısrarıyla bu sınırlar dâhilindeki Bulgar toprakları iki idari bölgeye...” ayrılmıștı: Tırnova merkezli Doğu ve Sofya merkezli Batı bölgeleri. “...Konferans...” her iki bölgede valilerin, garantör devletlerin tasvibiyle, Babıali tarafından tayin edilmesine “...karar vermişti”. Bundan başka toplantıda, yeni bölgelerde nahiye meclislerinin kurulması, bir (dâhili) nizamnamenin oluşturulması vd. hususlar “...öngörülmüştü”.

Öte yandan “...tüm Büyük devletler temsilcilerince oluşturulmuş ve imza edilmiş olan bu plan, Babıali'ye 21 Aralık 1876 tarihinde takdim...” edilmişti. Konferansın 23 Aralık 1876’teki “...resmi...” ilk oturumunda Safvet Paşa, Padişahın tebaasına bağışladığı Kanun-1 Esasi'nin ilan edilmesiyle “...delegeler tarafından teklif edilen projenin mana ve gereğinin kalmadığını...” belirtmişti. Ocak 1877'de Meclis-i Umumi “...sefirler konferansının tekliflerini...” nihai olarak reddetmişti. Neticede “...Türkiye’nin İstanbul Konferansı’nın kararlarını reddetmesiyle, Doğu sorununun yalnızca savaş yoluyla çözülebileceği kanaati ağırlık..." kazanmıştı (Stoyanov, 2003a: 705-707).

Bu satırları okuyan bir okurun, 11-22 Aralık 1876 tarihlerinde Rus sefaretinde yapılan gayrı resmi ön görüşmelerin bir konferans olduğunu ve bu toplantının, 23 Aralık itibariyle Osmanlı Devleti’nin de katılımıyla "resmen" devam ettiğini düşünmesi olasıdır. Özellikle Osmanlı tarafının, sefirlerin değil de konferansın tekliflerini (kararlarını) reddettiği yönündeki ifade, Devlet-i Aliyye'nin Konferansın muhatabı olduğu fakat katılımcısı olmadığı anlamına gelir gibidir. Hatta yukarıdaki anlatım tarzı, toplantıda yalnızca Avrupa sefirlerinin söz sahibi ve karar mercii oldukları intibaını yaratmaktadır.

Bundan başka Avrupalı sefirlerin önerileri, bu kaynağın farklı cümlelerinde "plan", "teklif edilen proje", "teklifler", "İstanbul Konferansı’nın kararları” ifadeleriyle anılmıştır. Dolayısıyla Mirât-ı Hakîkat'ta olduğu gibi bu metinde de "teklif" (proje) ve "karar" kelimeleri eş anlamda kullanılmıştır. Bu bağlamda Istoriya na Balgariya eserinde, literatürde evvelce rastlanan bir ifade tarzıyla tekrardan karşılaştı̆̆ımız belirtilebilir. Ancak bu metnin devamında Mir'ât-ı Hakîkat'tan ayrışan, tarihsel akışı olduğundan farklı algılatan bir anlatımı görüyoruz.

Eserde yer verilen yoruma göre, iki otonom Bulgar bölgesinin kurulması teklifi, fevkalade önemli bir “...uluslararası belgeydi...” (Bg.: mezhdunaroden akt; Eng.: international act). Bununla Bulgar ulusunun varlığı yalnızca “...tüm güçler tarafından... tanınmasıyla kalmamış, bu ulusun sınırları da belirlenmişti... Bu sınırlar küçük istisnalarla... Osmanlı Hükümetince Şubat 1870 'te çizilen sınırlarla örtüşmekteydi... Konferans katılımcılarının, müzakere edilen diğer konulardaki belirgin görüş farklarına rağmen... iki Bulgar bölgenin sınırları oybirliğiyle kabul edilmişti” (Stoyanov, 2003a: 706).

Bu yorum esasında aynı kitapta yer alan başka bir makalenin şu cümleleriyle bağlantılıdır: “...1870 yılında bileşik Bulgar ulusu, bizzat Osmanlı İmparatorluğu tarafından resmen 
tanındı. Bağımsız Bulgar Kilisesi’nin kuruluşu konulu 28 Şubat 1870 tarihli Fermanın 10. maddesinde Bulgar Eksarhlığı’nın sınırları belirlenmiştir. Bu sınırlar, üç klasik Bulgar bölgesi olan Moesia (Mezya), Trakya ve Makedonya dâhil olmak üzere, Bulgar nüfusunun çoğunlukta olduğu hemen tüm toprakları kapsıyordu” (Stoyanov, 2003b: 629).

Konuya henüz hâkim olmayan bir okur bu cümleleri okuduğunda, 1870 yilında Bulgar Eksarhlığı'nın kuruluşunu onaylamakla Osmanlı Hükümeti’nin esasen, tarih sahnesine yeni çıkmakta olan Bulgar ulusunun ülke sınırlarını belirlediği; ardından 1876 yılında İstanbul'da toplanan Avrupalı sefirlerin yaklaşık olarak aynı sınırları oybirliğiyle tasdik ettiği fikrine kapılabilir.

Bu fikrin ilk kısmı esasında İnalcık’n, Eksarhlık Fermanı’nın, Bulgar ulusunun tarih sahnesine çıkması bağlamında "ilk resmî vesika mahiyetinde" olduğu ve 10. maddesinde Bulgar ulusunun hudutlarını çizdiği sözleriyle aynı doğrultudadır (İnalcık, 1992: 17). Literatürde bu anlayışı paylaşan genel bir temayül de söz konusudur (Güllü, 2018: 355). Öte yandan Fermanın 10. maddesinde şehir, kasaba, köy, bir sancak, bir kaza, birkaç manastır, bir metropolitlik, hatta bir mahalle (Koyuncu, 1998: 100) türünden belirli yerleşimlerin belirtilmiş olması, burada Eksarhlığın sınırlarından (sathından) ziyade, yetkili olacağı birimlerden bahsedildiğine işarettir. Nitekim ilgili dönemde Balkanların çeşitlilik arz eden demografik yapısı; nüfus sayımında Bulgar tebaanın Gayrimüslimler içinden ayırt edilemeyişi ve Bulgar nüfus çoğunluğundan bahsedilemeyişi (Koyuncu, 2013: 203), anılan coğrafyada tek bir etnisitenin ikamet ettiğini söyleme imkânını vermemektedir.

Stoyanov'un yukarıdaki cümlelerinde, ilgili onayın "tüm Avrupa sefirlerince” verildiği yani, 1876 İstanbul Konferansı’nın ön görüşmelerinde kalıcı bir fikir birliğinin sağlandığı vurgulanır gibidir. Oysa 1878 Berlin Konferansı ile bunun kalıcı bir uzlaşı olmadığı anlaşılacaktı. Fakat 1876 'da bahsi edilen sınırlar sonradan, Bulgarlar adına uluslararası diplomaside dile getirilecek bir iddiaya konu olmuştur. Nitekim Stoyanov'un, Mezya, Trakya ve Makedonya’nın öteden beri Bulgarlara ait bölgeler oldukları hatta Bulgar Eksarhlı̆̆ı'nın kuruluşunu onaylarken Osmanlı Hükümetinin bunları, Bulgar toprakları olarak tanıdığı yönündeki ifadesi (Osmanlı Devleti'nin 1870 itibariyle Bulgar tebaası hakkındaki niyet ve düşüncelerini yansıtmamakla birlikte) bu iddiayla ilintili görünmektedir.

Dolayısıyla bu yorumda 1876'da Avrupalı “tüm güçlerin” anılan sınırlar konusunda resmen ve kalıcı olarak uzlaştıkları vurgusu, 1878 sonrasında kimi Avrupa Devletlerỉnin 1876 İstanbul Konferansı'nda mevzu edilen sınırları tanımamış olmalarına bir göndermeyi içerir niteliktedir.

Bu bağlamda Mirât-ı Hakîkat eserinde "alınan karar" ile "teklif” ifadeleri arasındaki eş anlamlılığın tesadüfi olduğu akla gelmektedir. Bunun Entsiklopedicheskiy Slovar' Brokgauza i Efrona'da belirtildiği üzere, Avrupa Devletleri arasındaki "keskin" fikir ayrılığının giderilmesi amacıyla ön görüşmeler yapılarak "uzlașı" ve "fikir birliği” sağlanması yani, "belirli bir karara" varılmasıyla paralellik arz ettiği belirtilebilir. 
Oysa Istoriya na Balgariya eserindeki "alınan karar" veya "İstanbul Konferansinın kararları" ifadeleri Avrupa Devletleri'nin (sonradan ilgili iddiaya konu olacak) Bulgar sınırlarını daha 1876 'da kabul ettikleri manasını aksettirmektedir. Buna göre Avrupa Devletleri evvelce onayladıkları toprak taksimatından 1878'de vazgeçmekle sözlerinden (kararlarından) dönmüştü. Dolayısıyla bu metinde "alınan karar" ifadesi vasıtasıyla, Bulgar toprak iddialarıyla ilgili olarak, Avrupa Devletleri'nin 93 Harbi'ni izleyen diplomatik hamlelerine eleştirel bir itiraz veya karşı-iddia dile getirilir gibidir.

Geçmiş olaylara itirazı, eleştiriyi dile getirmek her ülkenin milli tarih yazımı bağlamında anlaşılırdır. Ancak yukarıdaki örnekte, kelimeleri dolaylı anlamlandırma sebebiyle geçmişte vuku bulmamış olanın vuku bulduğu yani, alınmamış bir kararın alındığı yönünde algılanabilecek bir anlatım ortaya çıkmıştır.

Ders kitapları nispeten sınırlı bir okur kitlesine hitap etmektedir. Oysa günümüz dijital platformlarında bilgi son derece kolay, hızlı ulaşılabilir ve çoğaltılabilir. Burada yer alacak bilgilerin yetersiz veya geçersiz oluşu, doğru bilginin yaygınlaşmasını zorlaştırır. Nitekim popüler bilgi platformu Wikipedia'nın alternatifleri olan WikiOwl, WikiZero gibi gençlere hitap eden kaynaklarda İstanbul Konferansı́nın neticesine dair yanıltıcı cümlelerle karşılaşıyoruz: "Konferansta, ...Bulgaristan ve Bosna-Hersek'e özerklik verilmesi kararlaştırıldı. Osmanlı Devleti bu durumu kabul etmeyince Rusya Osmanlı Devleti’ne savaş açtı... Tersane Konferansı kâğıt üzerinde kalmış bir konferanstı. Konferansta tartışılan konular ancak 93 Harbi’nden sonra toplanan Berlin Antlaşması'yla kesinliğe kavuştu” (2019b, Tersane Konferansı). İngilizce örneğinde de benzer ifadeler geçmektedir: "Osmanlı Hükümetinin Konferans kararlarını reddetmesi 1877-1878 Osmanl1-Rus Savaşının başlamasına sebep oldu” (2019a, Constantinople Conference).

\section{1876 REİCHSTADT GÖRÜŞMELERİNDE “BULGARİSTAN" VE "RUMELİ" KONULU MUTABAKAT}

Rusya'nın Avusturya-Macaristan ile Temmuz 1876'da Reichstadt'ta ve Ocak 1877'de Budapeşte’de vardığı uzlaşılar incelendiğinde, İstanbul Konferansı’nın ön görüşmelerinde (11-22 Aralık 1876) Avrupalı sefirlerin geçici bir fikir birliğine ulaştıkları anlaşılıyor. Rupp'un ifadesine bakılırsa bunlardan altı ay evvelki Reichstadt müzakereleri, AvusturyaMacaristan'ın Rusya'ya diplomatik yolla tavizler verdiren uzun sürecin safhalarından biriydi (Rupp, 1925: 510). Öte yandan aşağıda değinileceği gibi bu müzakerelerin kayıtları tutarsızdır. Ancak Avrupalı devlet adamlarının Balkanlar coğrafyasına dair -sonradan Rumelideki idari taksimat bağlamında etkili olacak- algıları konusunda fikir vermektedir.

1876 Reichstadt görüşmelerinde uzlaşılan esasları incelerken Rupp, 1925’e değin neşredilen birkaç farklı metinden ikisini karşılaştırmıştır. İlki 1921'de İngiltere'de, ikincisi 1922'de SSCB'de yayınlanan örneklerden yola çıkarak Reichstadt'ta sözlü bir anlaşma sağlandığı neticesine varmıştır. Bu bakımdan yayınlanan belgelerin, anlaşma esaslarını hatırda 
tutmak amacıyla iki taraf temsilcilerince ayrı ayrı kaydedilen taslak metinler olduğunu söylemiştir (Rupp, 1925: 504, 510). Öte yandan Ocak 1877'de akdedilen ve resmen imzalanan gizli anlaşmada Reichstadt'taki uzlaşıya göndermede bulunulmuştur. Bundan dolayı Reichstadt görüşmeleri önem arz eder ancak uzlaşı esaslarının içeriği bağlamında güvenilir metin, Budapeşte Konvansiyonu’na Ek Sözleşme metnidir.

(26 Haziran) 8 Temmuz 1876 da Avusturya-Macaristan ile Rusya'nın temsilcileri Reichstadt'ta görüşerek, Osmanlı Devleti’nin Balkanlar'daki toprakları hakkında düşüncelerini karşılıklı olarak dile getirmiş ve bu bağlamda bazı kabullere varmıştı. Bu kabuller, Avrupa Devletleri’nin İstanbul Konferansı'na sunduğu Doğu ve Batı Bulgaristan Vilayetleri tavsiyesinin arka planını ayrıca, 1878 Berlin Antlaşmasının bu konudaki kararlarını anlamaya yardımcıdır. Așağıda 1921'de ve 1922'de neşredilen iki metinden hareketle tarafların, özelde Bulgaristan ve Rumeli konulu uzlaşı esasları aktarılmıştır.

1922'de Krasnyy Arhiv dergisinde yayınlanan “Tekst Reyhshtadtskogo Soglasheniya” metninde muhtemel bir savaşta, Osmanlı Devleti’nin yenilgiye uğraması ve Avrupadan (Balkanlar'dan) 1- kısmen (buradaki bazı topraklarından) ya da 2- tümüyle (buradaki tüm topraklarından) çekilmesi koşulunda iki yol izlenebileceğinden bahsedilmekteydi. Birinci olasılığın gerçekleşmesi durumunda Karadağ, Sırbistan, Hersek, Bosna, Hırvatistan, Besarabya’yla ilgili kabuller konu edilmişti. Taraflar bölgede büyük bir Slav devletinin kurulmasını desteklemeyecek fakat Karadağ ile Sırbistan bileşebilecekti.

Osmanlı Devleti’nin Balkanlar'dan tümüyle çekilmesi koşulunda ise Bulgaristan ve Rumeli “...kendi doğal coğrafyalarında bağımsız prenslikler kurabilecekti”. Epir ile Tesalya Yunanistan’a bağlanmada hür olacak, İstanbul’a hür şehir statüsü verilecekti (Baykal, 1941: 371-373, 393-394; Tekst Reyhshtadtskogo, 1922b: 38).

Pribram tarafından 1921'de neşredilen "Résumé des Pourparlers Secrets de Reichstadt du 8 Juillet 1876" adlı özet metinde ise aynı husus şöyle belirtiliyordu: "Bulgaristan, Rumeli ve Arnavutluk otonom devletler kurabilecek; Tesalya ile Girit Yunanistan’a bağlanacaktır. Kapsayacağı bölgeler belirlenecek olan İstanbul, hür bir şehir olacaktır” (Pribram, 1921: 190).

15 Ocak 1877'de Budapeşte’de akdedilen Rusya - Avusturya-Macaristan Gizli Sözleşmesi ve buna ilave edilen Ek Sözleşme, hem Pribram'ın kitabı hem de Krasnyy Arhiv'in aynı sayısında neşredilmiştir. Bulgaristan ve Rumeli konusu özelinde iki eserdeki bu metinler aynıdır. Ek Sözleşme’nin 3. maddesine göre: “...Reichstadt’taki görüşmelerinde taraflar prensip olarak şu hususlarda uzlaşmıştır: Osmanlı Devleti’nin toprak bütünlüğünde değişiklik olması ya da bu devletin tümüyle dağılması durumunda büyük bir Slav veya başka devletin kurulması düşünülemez; bunun rövanşı olarak Bulgaristan, Arnavutluk ve Rumeli’nin kalan bölgeleri bağımsız devletler olarak tesis edilebilecektir; Tesalya, Epir'in bir kısmı ve Girit Yunanistan'a bağlanabilecektir; kapsayacağ bilahare belirlenecek olan İstanbul hür bir şehir olabilecektir" (Pribram, 1921: 200-202; Convention secrète, 1922a: 60). 
Pribram'ın derlemesine göre, Reichstadt uzlaşısında Bulgaristan ve Rumeli'nin otonom devletler; Budapeşte anlaşmasında ise bağımsız devletler kurabileceklerine kanaat edilmişti. Krasnyy Arhiv'de neşredilen metinlerine göre ise Reichstadt'ta Bulgaristan ve Rumeli'nin kendi doğal coğrafyalarında bağımsız prenslikler kurabilecekleri düşünülmüşken, Budapeşte’de doğal coğrafyalarına değinilmeksizin, bă̆ımsız devletler olarak tesis edilebileceklerinde uzlaşılmıştı.

Pribram'in eserine bakılırsa 1876 İstanbul Konferansı evvelinde Balkanlar'da, "Bulgaristan" ve "Rumeli" adıyla özerk prensliklerin değil, otonom devletlerin kurulması tasarlanmaktaydı ve bunların kapsayacağı bölgeler mevzu edilmemişti. Krasnyy Arhiv'de ise Balkanlar’ın yüzey şekilleri dolayısıyla doğal olarak ayrışan iki coğrafyasında iki özerk prensliğin tesisinden bahsedilmekteydi. Taraflar, küçük ölçekli bu özerk idarelerin kurulmasını, büyük bir Slav devleti oluşturmamanın karşılığında onaylıyordu.

Tarihsel süreçte Balkan Yarımadasının çeşitli bölgelerini adlandırmada kullanılan coğrafi tabirler değişmiştir. Ayrıca, "Bulgaristan" ve "Rumeli" adlarıyla anılan coğrafyalar ve kapsamları da farklılaşmıştır.

1876 yılı itibariyle bu adlarla hangi coğrafyaların bağdaştırıldığını 19. yy. haritalarından teyit etmek mümkündür. Kiepert'in 1855 ve Wyld'in 1856 tarihli haritalarında kuzeyde Tuna, batıda Drina nehri, doğuda Karadeniz ve güneyde Balkan sıradağları arasında kalan düzlük "Bulgarien; Bulgaria (Bulgaristan)" olarak ve kuzeyde Balkan sıradağları, doğuda Karadeniz güneyde Tesalya ve batıda Arnavutluk ile sınırdaş bölge "Rumili; Rumelia" (Rumeli) olarak işaretlenmiştir (Kiepert, 1855; Wyld, 1856). Anılan coğrafi bölgeler 1827 yılının Avrupa Türkiyesi ve Yunanistan Genel Haritasında da aynı isimlerle belirtilmiştir (Lapie, 1827). Harenberg'in 1741 tarihli haritasında ise bunlar, eskiçağdan beri bilinen isimleriyle gösterilmiştir: "Moesia Superior”, "Moesia Inferior" (Bulgaristan) ve "Macedonia”, “Thracia” (Rumeli) (Harenberg, 1741).

Dolayısıyla Krasnyy Arhiv'de neşredilen Reichstadt uzlaşısına göre "Bulgaristan” ile "Rumeli" adlarıyla anılan doğal coğrafyalar, Balkan sıradağlarının yatay eksende bölerek oluşturduğu, biri kuzeyde diğeri güneyde kalan iki bölge olmalıydı. Pribram’nn neşrettiği metinde Reichstadt görüşmeleri kapsamında bahsedilmemiş olan bu doğal coğrafyaların Krasnyy Arhiv'de anılıyor olmasına dayanarak bunların, 1876'da Rus devlet adamlarınca bilindiği veya algılandığı söylenebilir.

Öte yandan özellikle İngiltere ile Avusturya-Macaristan açısından Balkan sıradağları, Rusya’nın Karadeniz’e hâkim olup Akdeniz’e inme hedefi bağlamında, aşılmasına izin veremeyecekleri doğal sınırdı (Baykal, 1941: 353). Nitekim 1878 Berlin Konferansı'nı takiben Balkanlar'da (yaklaşık olarak), Reichstadt'ta bahsi geçtiği aktarılan "Bulgaristan" ve "Rumeli" doğal coğrafyalarında, aralarındaki sınır Balkan sıradağları olmak üzere, muhtar Bulgaristan Emareti ile Osmanlı Devleti’ne bağlı özerk Şarki Rumeli Eyaleti tesis edilecekti (Stanford, 1886; Grossmann, 1894). 


\section{1876 İSTANBUL KONFERANSI'NIN AÇILIŞI VE SEFIRLERIN DOĞU VE BATI BULGARISTAN VILLAYETLERİ ÖNERISII}

Konferansın açllısında Avrupa Devletleri temsilcileri toplantının “...bu güne değin Doğu'da barışı temin için sarf edilen çabayı yararlı bir sonuca ulaştırmak...” amacıyla tertiplendiğini belirtmiştir.

Konferansı açış konuşmasında Safvet Paşa son 18 aylık süreci özetlemiştir: MayısHaziran 1874’te Karadağ’a komşu olan bazı Hersek köylerinde meydana gelen asayişsizlik dolayısıyla Kont Andrassy, Babıali'ye bu bölgede bir reform yapılmasını önermişti. Sorunları ortadan kaldırmayacağını bildiği halde Osmanlı Hükümeti, Kont Adrassy’nin tavsiyelerine uyarak, yeni ıslahat yapacağının teminatı olarak bir İrade yayınlamıştı (BOA, HR.SYS.1289/1-14-18; Baltalı, 1987: 206-207). Ancak 1876 başlarında asayişsizliğin çemberi genişleyerek bazı Bulgar köylerini de kapsamıştı.

1874’teki Bosna ve Hersek olayları tecrübesiyle Osmanlı Hükümeti, asayişin ivedilikle sağlanmasıyla bölgede başka vukuat çıkmayacağını düşünmüştü. Ancak Mart 1876'da bu kez Balkan dağı yakınlarındaki bazı köylerde “...evvelce Padişahın aleyhinde hiçbir eylemde bulunmamış, Müslüman ve Hıristiyan tebaanın yan yana yaşadığı sakin ve müreffeh bir bölgede aniden şiddetli bir isyan...” başlamıştı. Tahkikat sonrasında ayaklanmanın uzun zamandır planlandığını hatta “...iç savaşı başkentin kapılarına kadar...” taşımayı hedeflediği anlaşılmıştı. Filibe olayları, Osmanlı Devleti aleyhindeki “... büyük komplonun küçük bir parçası...” idi (BOA, HR.SYS.1289/1-14-18: 3 vd.).

Safvet Paşa’nın sözleriyle oysa 1856 Paris Antlaşmasını takiben Osmanlı Devleti Rumeli’nin diğer bölgelerine nazaran Bulgarlarla meskûn bölgelerde en fazla mülki ve idari iyileştirmelerde bulunmuştu. Bulgar nüfusunun manevi ihtiyaçları Osmanlı Devleti’nin hususi ilgisine mazhar olup 1870’te Bulgar Eksarhlığ 1 kurulmuştu. Hatta bu ilgi sebebiyle diğer tebaa Osmanlı Hükümeti’ni, Bulgarları kayırmakla yermişti. Bundan dolayı Devlet-i Aliyye'nin nazarında, gayet alakadar olduğu Bulgarların son ayaklanmaları, yapılan iyileștirmelerin suiistimaliydi. Diğer yandan Babıali, Balkanlar'da meydana gelen ve ülke huzurunu bozmak, tebaanın can güvenliğini tehlikeye atmak amacındaki bu isyanların, yabancı devletlerin anılan tebaaya olumsuz tesiriyle çıktığı görüşündeydi. Buna rağmen Hükümet, asayişi temin eder etmez, sadece bu bölgeleri kapsayacak yeni bir islahat projesini Avrupa Devletleri’nin dikkati ve tasvibine sunmuştu.

Bu olayların cereyan ettiği son aylarda Babıali ayrıca, aynı devletlerin tavsiyelerine saygı gösterip yeni sorunların zuhurunu önlemeye ve mevcut olanları azaltmaya çalışmıştı. Yeni bir siyasi ve idari düzenin prensiplerini belirleyerek “... Osmanlı tebaasının unsurları arasında coğrafi konum ya da etnolojik karakter...” bakımından ayrım yapmayan, tüm Osmanlılara eşit hukuki ve siyasi hakları tanıyan Kanun-1 Esasi'yi ilan etmişti. Bununla Hükümet, bölgelerce seçilmiş vekillerden müteşekkil Vilayet Meclisleri ayrıca, seçilmiş üyelerden oluşan ve yerel idareleri bir âdem-i merkezileşme programı çerçevesinde denetleyecek Kaza Meclisleri aracılığıyla, tebaasına kendini temsil etme hakkını 
bahşediyordu (BOA. HR.SYS. 1289/1-14-18: 13).

Safvet Paşa’nın sözleriyle bu yeni âdem-i merkezileşme programı, devletin bütünlüğüne ve merkezi iradenin korunmasına duyulan saygılla uyum halindeydi. Kanun-1 Esasi'yi ilanla Osmanlı Devleti, yerel müesseselerin koruyucusu olarak doğrudan doğruya memleketi tayin etmiş, böylece islahat projesinin eksiksiz ve samimi olarak icra edileceğine en büyük teminatı sunmuştu. Neticede Osmanlı Devleti’ni altüst etmeyi ve Avrupa’nın huzurunu sarsmayı amaçlayan isyan girişimlerine Babıali, metaneti ve itidali sayesinde hâkim olabilmişti. Bundan sonrası için Avrupa Devletleri, Kanun-1 Esasi ile ülkedeki düzeni yeniden tesis edeceği konusunda Osmanlı Hükümeti’ne güven duymalıydı.

Safvet Paşa’nın açış konuşmasının ardından Lord Salisbury ile General İgnatiyev, katılmadıkları bu sözlere pek çok noktada itiraz edebileceklerini söylemiştir. Sefirler Konferansın geçen yaz aylarında Bulgaristan'da meydana gelen olayları tartışmak için toplanmadığını belirtmekle yetinmiş ve Kanun-ı Esasi mevzuunu dikkate almayarak Osmanlı Hükümeti nezdinde yeni bir reform önerisini sunma gündemine geçmişlerdir (BOA. HR.SYS. 1289/1-14-18: 16 vd.).

Avrupa Devletleri'nin önerisi sırasiyla "Sirbistan", "Karadağ", "Bulgaristan", "BosnaHersek", "Bosna-Hersek Beynelmilel Komisyonuna Verilecek Talimat" ile "Bulgaristan Beynelmilel Komisyonuna Verilecek Talimat” başlıklarıyla düzenlenmiş A, B, C, D, E, F eklerini içeriyordu. "Bulgaristan" başlıklı Ek-C'de yer alan "Projet de Règlement Organique" (Dâhili Nizamname Projesi) on maddeden oluşuyordu.

Birinci maddede, Osmanlı Devleti'nin mevcut idari taksimatında Tuna, Edirne, Selanik ve Manastır Vilayetlerinin tüm ya da bazı sancak ve kazalarını kapsayacak biçimde, biri Doğu, diğeri Batı olmak üzere iki vilayetin kurulması (daha doğrusu, mevcut vilayetlerin taksim edilmesiyle iki yeni idari bölgenin oluşturulması ve bunlara yeni adlar verilmesi) önerilmekteydi. Buna göre iki yeni vilayete bağlı olması düşünülen sancak ve kazalar aşağıdaki gibi sıralanmıştı:

1- Doğu Vilayeti, merkezi Tirnova olmak üzere Rusçuk, Tirnova, Tulça, Varna, İslimiye ve Sultanyeri ile (Ahiçelebi hariç ve Kırkkilise, Cisr-i Mustafa Paşa ve Kızılağaç kazaları dâhil olmak üzere) Filibe sancaklarını kapsamalı;

2- Batı Vilayeti, merkezi Sofya olmak üzere Sofya, Vidin, Niş, Üsküp, (güneyindeki iki kaza hariç) Manastır sancaklarını, Serez sancağının kuzeydeki üç kazası ile Usturumca, Tikveş, Veleş ile Kesriye (Kostur) kazalarını içeriyor olmalıydı.

İkinci maddede iki vilayetin idari yapısı bağlamında tatbik edilmesi düşünülen esaslar öneriliyordu. Bunlar:

1- İki vilayetin en küçük idari biriminin en az beş, en fazla on bin nüfuslu nahiyeler olmasi; 
2- Mevcut idari taksimata olabildiğince bağlı kalınarak Hıristiyan ve Müslüman nüfusun ayrı nahiyelerde toplanması;

3- Nahiye müdürünün, nahiye meclisince, meclis üyeleri arasından dört yıllı̆̆ına seçilmesi;

4- Nahiye meclislerinin her bucaktan, din farkı olmaksızın, dört yıllığına seçilecek vekillerden oluşması;

\section{5- Bucakların mevcut teşkilatının korunması;}

6- Azınlıkların nahiyelerde temsil edilmesini sağlamak üzere devletlerarası bir komisyonun çalışmalar yapması;

7- On bin kişiden fazla nüfusu olan şehir ve kasabaların, nahiyelere benzer idari encümenlere sahip olmasiydı.

Üçüncü maddedeki öneriye göre nahiyeler kaymakamlarca idare edilen sancaklar halinde birleştirilmeliydi. Nahiye meclislerindeki düzeni ve işleri denetlemekle görevli olacak olan kaymakamlar, sancağın nüfus yoğunluğuna göre Hıristiyan ya da Müslüman olmalı ve Vali’nin tavsiyesiyle Babıali tarafından dört yıllığına tayin edilmeliydi. Vali, kaymakamları üç aylık süreyle görevden alma ve Babıali’ye yerlerine başka kişilerin getirilmesini tavsiye etme yetkisini haiz olmalıydı.

Dördüncü maddede her vilayetin başında, Osmanlı Hükümeti’nce beş yıllığına seçilip, tayini Avrupa Devletleri'nce onaylanan bir Genel Valinin bulunması önerilmekteydi. Yüksek otoriteyi temsil edecek olan Valinin, Osmanlı Devleti'nin kanunları ile Vilayet Nizamnamesinin tatbikini denetlemesi; Osmanlı tebaasından ya da yabancı uyruklu bir Hıristiyan olması ve bir Vilayet Meclisinin desteğiyle görev yapması tavsiye edilmekteydi. “...Babıali'nin dahli olmadan, ırk (milliyet) ya da din farkı gözetmeksizin...” nahiye meclislerince dört yıllığına seçilmesi düşünülen Vilayet Meclisi, kanun ve Nizamnameyle ilgili düzenlemeler haricindeki tüm durumlarda Vali’ye danışmanlık yapmalıydı.

Projenin devamdaki maddelerinde idari, iktisadi, hukuki, askeri konularda uygulanması düşünülen esaslar sıralanmıştı. Bunlardan bazıları, dini hürriyetin teminat altına alınması; mahkemelerde ve idari işlerde ilgili memlekette konuşulan dilin (Bulgarca), Türkçe ile eşit statüde kullanılması; yaygın olarak konuşulduğu bölgelerde Rumcanın otoritelerce kullanılabilmesi; Rumelideki Osmanlı düzenli askeri birliklerinin yalnızca kalelerde ve başlıca şehirlerde konuşlandırılması ve görevlerinin öncelikle ülkeyi dış tehditlerden korumak olması fakat savaş durumunda ya da Genel Vali'nin isteği üzerine ülke dâhilinde seferber edilebilmeleri; kurulması önerilen yeni vilayetlerde, Hıristiyan ve Müslüman nüfus miktarına mukabil sayıdaki neferlerden müteşekkil bir milis kuvveti ve jandarmanın oluşturulması idi. 
Osmanlı Hükümetine sunulan bu Projenin, Konferans sonunda imzalanacak Protokolü takiben üç ay zarfında uygulamaya konması tavsiye edilmekteydi (BOA, HR.SYS. 1289/1181, 182: 1).

Bundan başka Ek-F’de, genel olarak Konferans tarafından düzenlenen nizamnamelerin tatbikini, özelde ise idari ve hukuki kurumların işleyişini ve seçimleri denetleyecek bir milletlerarası komisyonun kurulması önerilmekteydi. Komisyon, vilayetlerin coğrafi sınırlarını belirleme çalışmalarına da iştirak etmeli; nüfus dağılımını eşitlemek amacıyla demografik bilgiler derleyerek Osmanlı otoritelerinin yardımıyla mahallinde, sancakların, nahiyelerin ve vilayetlerin sınır çizgilerini tespit etmeli, vilayet sınır bölgelerinde bulunan kazalara nahiye ekleyebilmeli ya da kazalardan nahiye eksiltebilmeliydi. Buna ilaveten coğrafi, etnografik ya da idari sebeplerle gerekli bulduğu takdirde, sancak ve nahiye taksimatını değiştirebilmeliydi (BOA, HR.SYS. 1289/1-147).

\section{OSMANLI HÜKÜMETI'NINN SEFIRLERIN TAVSIYYLERINNE İTIRAZI VE KARŞI- ÖNERILERI}

Osmanlı Hükümeti sefirlerce sunulan tavsiyeleri incelemiş fakat kabul etmemiştir. Konferansın 28 Aralık 1876'daki ikinci oturumunda itiraz gerekçesinin, Osmanlı Devleti’nin toprak bütünlüğü ve bağımsızlığı ilkelerini gözetme gereği olduğu izah edilmiştir.

Safvet Paşa’nın sözleriyle, bu iki husus Babıali’nin önceliği olup, 1856 Paris Muahedesi esasları ve hâlihazırda toplanan Konferansın amacıyla tam olarak bağdaşmaktaydı. Oysa yeni sunulan öneriler Osmanlı Hükümeti’ne göre, mevzubahis önceliklerin aleyhineydi. Konferans evvelindeki teatiye göre müzakere konularından bir tanesi, "Avrupa Türkiyesi'nin kuzey vilayetlerine" yerel müesseseler düzeninin (âdem-i merkeziyetin) bahşedilmesi olacaktı. Bosna-Hersek ile Tuna Vilayetleri özelindeki bu reform düşüncesi doğrultusunda, görüşmeler başlamadan, söz konusu yerel müesseseler düzeninin bazı esasları belirlenmişti. Âdem-i merkezi düzende vilayet sakinlerine, mahalli idarecileri denetleme imkânı sunulacaktı. Tebaa, mahallerindeki idarecilerin keyfi icraatına karşı güvencelere kavuşturulacaktı. Osmanlı Hükümeti, Bosna-Hersek ile Tuna Vilayeti hususunda Konferans öncesinde teklif edilen bu esasları, 1856 Paris Antlaşmasıyla uyumlu oldukları sebebiyle olumlu karşılamıştı. Bizzat Hükümet, memalik-i şahanede daha kapsamlı ıslahatların yapılması gerektiği fikrindeydi.

Ancak ilk oturumda sunulan öneride, Safvet Paşa'nın sözleriyle, Osmanlı Devleti için beklenmedik, ön görüşmelerde bahsi geçmeyen ve Konferansın toplanma amacına uymayan taleplere yer verilmişti. Bundan dolayı Babıali özelde Bulgaristan konusundaki şu hususları kabul edememekteydi:

1- Milletlerarası bir Komisyonun oluşturulması; 
2- Yabancılardan oluşan bir jandarma birliğinin kurulması;

3- Osmanlı askeri birliklerinin sadece kalelerde konuşlandırılması;

4- Vali ve diğer idarecilerin tayin edilme usulü;

5- Teklif edilen idari taksimat şekli;

6- İktisadi ve hukuki düzenlemeler;

7- Çerkez asıllı nüfusun Anadolu’ya nakli (BOA, HR.SYS. 1289/1-19-25).

$\mathrm{Bu}$ sıralamaya göre önerilen idari taksimat, itiraz edilen beşinci husustu. Osmanlı Hükümeti'nin önceliği, milletlerarası bir komisyonun teşkili ile bölgedeki askeri ve siyasi işlerin yabancılarca denetlenmesine müsaade edilemeyeceğiydi.

Safvet Paşa’nın devamdaki sözleriyle Babıali, ülkenin kuzey vilayetlerinde barış ve refahı temin bağlamında tebaanın aşırı heyecanına ve endişesine sebep olmayacak, idari yapıyı altüst etmeyecek, büyük çatışmalar doğurmayıp mevcut aleyhtarlığın sürmesine yol açmayacak tedbirleri gerekli addediyordu. Osmanlı Hükümeti bunları sağlayamayacak önerilerden istifade edemezdi.

$\mathrm{Bu}$ konuşmayı takiben General İgnatiyev, Bulgaristan meselesi özelinde Osmanlı Devleti’nin toprak bütünlüğünü muhafaza etmekten bahsedilemeyeceğini söylemiştir. Oturumun devamında Sırbistan, Karadağ ve Bosna-Hersek konuları müzakere edildikten sonra iki Bulgaristan vilayeti meselesine dönülerek, İngiltere tarafından Konferans öncesinde gönderilen mektupta (BOA, HR.SYS. 1289/1-6; Küçük, 1980: 127), Bosna ve Hersek için önerilenlerin, Tuna Vilayeti bağlamında da tavsiye edildiğine değinilmiştir. Mevzubahis mektupta Osmanlı Devleti’nin bazı eyaletlerinde mahalli ve idari muhtariyet usulünü getirme konusunun müzakeresi önerilmekteydi.

Oturumun devamında, Babıli'ye sunulan sslahat önerilerinin madde madde görüşülmesine geçilmiştir. Sıra Tuna Vilayeti topraklarında kurulması tavsiye edilen iki yeni vilayet ile bunların sınırları maddesine geldiğinde Safvet Paşa, Osmanlı Hükümeti’nin bu idari taksimatı kabul edemeyeceğini belirtmiştir. Zira onun sözleriyle, son isyanların sebebi mevcut idari bölünme değildi. Ayrıca ilgili bölgelerde, önerilen yeni düzeni kabul etmeyecek olan bir kısım ahali yaşamaktaydı (BOA, HR.SYS. 1289/1-19-25).

Ardından Edhem Paşa, ilgili iki vilayet sınırlarının bu haliyle önerilmiş olmasının gerekçelerini sormuştur. Onun sözleriyle memalik-i şahanede vilayet sınırları idari ihtiyaçlar dolayısıyla evvelce değişikliğe tabi tutulmuştu. $\mathrm{Bu}$ bağlamda Osmanlı Devleti'nin mevcut idari taksimatı zamanın ve tecrübenin eseriydi ve hâlihazırda yeni bir düzenlemeye gerek yoktu; nitekim bu önerilere bizzat bölge sakinlerince karşı çıkılacağı kuşkusuzdu. 
Edhem Paşa’ya cevaben Lord Salisbury önerdikleri idari taksimat yoluyla, “...inançları ve ırkları...” mümkün olduğunca ayırmaya çalıștıklarını belirtmiştir. Bunun üzerine Edhem Paşa milletlerin kaynaşması arzusunda olduğundan Osmanlı Hükümeti’nin, milletleri ayırma prensibine göre düzenleme yapamayacağını söylemiştir. General İgnatiyev ise önerilerinin, mevcudu aynı bırakılan sancak ve kazaların yalnızca (farklı biçimde) gruplanmasından ibaret olduğunu dile getirmiştir. Fakat bu da yeterli bir gerekçe oluşturmadığından Safvet Paşa’nın hâlihazırdaki idari taksimatın korunması yönündeki ısrarıyla, bu meseleyle ilgili görüşmeler bir süreliğine askıya alınmıştır.

Diğer yandan Konferansın ikinci oturumunda, kapsayacağı nüfus miktarı bilahare belirlenmek üzere, idari birimin nahiye olması esası Osmanlı tarafınca kabul edilmiştir. Aynı oturum esnasında Safvet Paşa, iki vilayetin tesisi konulu Ek-C’nin "Bulgaristan" başlığıyla düzenlenmiş olmasının tezat oluşturduğunu, Osmanlı Hükümeti’nin bu başlığ1 kabul edemeyeceğini söylemiștir. Sefirler "Bulgaristan" adının, Ek-C’yi diğer eklerden ayırmak üzere kullanıldığını belirtmiştir (BOA, HR.SYS. 1289/1-19-25). Aynı mevzu Konferansın altıncı oturumunda yeniden gündeme gelmiş ve sefirler bu kez farklı bir yanıt sunmuştur.

Konferansın 30 Aralık 1876 tarihli üçüncü oturumunda Safvet Paşa Babıali’nin Rumeli'de ıslahat konusunda yeni bir öneri hazırladığını duyurmuştur. Tercümesi 1 Ocak 1877 tarihli dördüncü oturuma yetiştirilen bu tekliflerde Balkanlar'da Doğu ve Batı Bulgaristan Vilâyetleri kurulması tavsiyesi bulunmuyordu. Bunların ilk maddesi "Vilayetler sancaklara, sancaklar kazalara, kazalar nahiyelere, nahiyeler de köylere bölünecektir” idi. Devamda mevcut vilayetlerdeki idari düzenin ayrıntıları, meclis seçimleri, vergilerin toplanması, askeri hizmet vb. konulardaki öneriler yer alıyordu.

Tekliflerin beyanını takiben Lord Salisbury bunları tenkit etmiştir. Onun sözleriyle Babıali, sefirlerin önerdiği jandarma kuvvetlerinde yabancı askerlerin kullanılması, milletlerarası bir denetleme komisyonu teşkili, ondalık vergisinin kaldırılması, yeni vergi düzeni, mahkemelerin kuruluşu, hâkimlerin tayin şekli ve görev süresi, çeşitli kurulları seçme usulü ve bunların yetkileri vd. hususlara değinmiyordu. Salisbury’ye göre, Avrupa’da barışı sağlamak ve Osmanlı tebaasının durumunu iyileştirmek için bizzat, en uygun tavsiyelerde bulunmuşlardı. Bundan dolayı kendi önerilerini sunmakla Babıali, sefirlerin bazı tavsiyelerini reddetmekteydi. Neticede sefirler Babıali’nin önerilerini müzakere etmeyeceklerini beyanla, kendi önerilerinin kesin olarak reddedilip edilmediğini sormuşlardır. Safvet Paşa bu husustaki cevabı Meclis-i Umumi'ye danıştıktan sonra bildireceğini söylemiştir (BOA, HR.SYS. 1289/1-29-32).

Bunların haricinde oturumda Babıali’nin Doğu ve Batı Bulgaristan Vilayetleri teşkilini reddettiğine dair bir eleştiri yapılmamış, müzakerelerde Bulgar meselesi tekrardan ikinci planda kalmıştır. 


\section{BABIALI'NIN SEFIRLERIN TAVSIYYLLERINI KABUL EDEMEYIŞ SEBEPLERINII İKINCİ KEZ İZAHI}

Dördüncü oturumda sorulan soruya cevaben 4 Ocak 1877'deki beşinci oturumda Safvet Paşa, Osmanlı Hükümeti’nin sefirlerin tavsiyelerini ret sebeplerini yeniden izaha çalışmıştır. Ancak ikinci oturumda dile getirilenlerle aynı olmakla birlikte ilgili sebepler bu kez farklı bir öncelik sırasıyla beyan edilmiştir. Aşağıda bunlar 4 Ocak gününde duyuruldukları gibi aktarılmış, ikinci oturumda belirtilme sıraları parantez içinde verilmiştir:

1- Milletlerarası bir komisyonun teşkili (1. sırada, değişiklik yok),

2- Yabancı jandarma birliğinin oluşturulması (2. sırada, değişiklik yok),

3- Önerilen idari taksimat (5. sırada),

4- Düzenli Osmanlı birliklerinin konuşlandırılma şekli (3. sırada),

5- İktisadi düzenlemeler (6. sırada),

6- Hukuki düzenlemeler (6. sırada),

7- Vali ve diğer idarecilerin tayin şekli ve yetkileri (4. sırada),

8- Çerkezlerin iskânı (son sırada, değişiklik yok).

İki sıralama karşılaştırıldığında beşinci oturumda Osmanlı Devleti'nin yabancı müdahaleye müsaade edemeyeceğinde israrlı olduğu (1. ve 2. sebepler); sıralamadaki değişiklikten ise görüşmelerin seyriyle askeri birlikleri konuşlandırma, vali ve idarecilerin tayini konularına kıyasla önerilen idari taksimatı reddetmenin önem kazandığı anlaşılmaktadır.

Konuşmasında Safvet Paşa milletlerarası bir komisyona verilmek istenen yetkilerin, Bosna ile önerilen Doğu ve Batı Vilayetlerinde Devlet-i Aliyye’nin otoritesinin görmezden gelinmesine yol açacağına değinerek bunun, 1856 Paris Muahedesi hükümlerine aykırı olacağını belirtmiştir.

Safvet Paşa ikinci oturumda, mevcut idari taksimattaki değişikliklerin hangi gerekçeyle önerildiğini beyhude sorduklarını söylemiştir. Zira (açış konuşmasında da dile getirdiği gibi) Edirne Vilayetinde meydana gelen olaylar ile hâlihazırdaki idari düzen arasında herhangi bir ilgi bulunmamaktaydı. Nitekim Safvet Paşa’nın sözleriyle, İngiltere’nin Konferansın toplanmasına davet mektubunda idari taksimatın bahsi edilmemiş; şimdi ise sefirler bu tavsiyeye gerekçe sunmaktan kaçınmaktaydı. Bundan dolayı Babıali şimdilik, böyle bir değişikliğin ciddi sorunlar doğuracağına dikkatleri çekmekle yetinmekteydi.

Safvet Paşa’nın sözleriyle, sunulan projenin başlı̆ğnda "Bulgaristan” adının kullanılmış 
olması Babıali nazarında, sefirlerin söylediği gibi ehemmiyetsiz bir husus değildi. Ek-C’nin 1. maddesinde Avrupa Türkiyesi’nde yaşayan Bulgar nüfusunu bu iki vilayette toplayarak, bunun çoğunlukta olacağı iki idari birimin meydana getirilmek istendiği anlaşılıyordu. Oysa etnisiteye dayalı ayrım Osmanlı ülkesine gereğinden fazla acı yaşatmıştı. Bunun tekrarını önleme amacındaki Kanun-ı Esasi tam da ilân edilmişken, Bulgar tebaayı müstakil idari birimlerde toplama önerisi Babıali tarafından kabul edilemezdi (BOA, HR.SYS. 1289/1-35-38). Nitekim Kanun-1 Esasi'nin ilk maddesi "Devleti Osmaniye memalik ve kıtaatı hazırayı ve eyalatı mümtazeyi muhtevi ve yek vücud olmağla hiç bir zamanda hiç bir sebeble tefrik kabul etmez" olarak düzenlenmişti (Gözübüyük ve Kili, 1982: 27).

Devamdaki konuşmalarında Osmanlı temsilcileri ilgili bölgelerde, Müslüman ve Gayrimüslim tebaanın idari bir değişikliğe razı olmayacağına ve bu bağlamda üstesinden gelinemeyecek bir direnç göstereceğini yinelemişlerdi. Bundan başka, iki yeni vilayetin kapsayacağ1 sancak ve kazalardaki Müslüman nüfusun akıbeti meselesinden ve söz konusu değişikliğin Hristiyan Bulgar nüfus için doğuracağı ciddi sakıncalardan bağımsız olarak; Vidin'den başlayıp Selanik kapılarına uzanacak bir vilayet (Batı Vilayeti) kaçınılmaz olarak Rum nüfusun yoğunlaştı̆̆ 1 bölgeleri de kapsayacaktı. Sefirler bu sebeple olsa gerek önerilerine, Rum nüfusun çoğunluk olduğu bölgelerde idari dilin Rumca olması hususunu eklemişti. Safvet Paşa’nın ifadesiyle, bu Avrupa Devletleri’ne belki yeterli bir önlem olarak görünmüştü. Ancak Babıali’nin temsilcilerine göre Hıristiyan tebaanın etnik özellikleri konulu tavsiyeler, Konferansın barışı tesis etme arzusuyla tezattı. Nitekim Osmanlı memleketini bilenler, önerilen bu iki vilayetin kurulması halinde pek çok mahalde Rumlar ile Bulgarlar arasında husumetin baş göstereceğinden şüphe etmezdi.

Bu çerçevede Osmanlı Devleti, tavsiye edilen idari taksimatı şu sebeplerle reddetmekteydi:

1- Bu öneri İngiltere’nin Konferansı toplama davetinde yer almıyordu, dolayısıyla Konferans'ta müzakeresi ilkece aykırıydı;

2- Yeni ilan edilen Kanun-1 Esasi milliyet ayrımını ortadan kaldırıyordu, oysa idari taksimat buna yeniden zemin oluşturabilirdi;

3- İdari taksimat bir yandan Müslüman-Hıristiyan, diğer yandan Rum-Bulgar anlaşmazlığına yol açabilirdi.

Buna cevaben Lord Salisbury İngiltere’nin mektubunda, Bulgaristan için idarecilerin olumsuz muamelelerine karşı bazı garantilerin üstü kapalı olarak talep edildiğini söylemişse de bununla Safvet Paşa’nın sözlerine geçerli bir yanıt sunmamıştır (BOA, HR.SYS. 1289/1-35-38).

Öte yandan Konferans toplanmadan evvel Babıali ile yazışmalarında İngiltere Hariciye Nezareti “...Konferansa esas olarak kullanılan mahallî muhtariyet sözü, hiçbir muâhedede kullanılmamıştır. Diploması nazarında manası meçhuldür. Tatbik edilecek eyâletlerde 
Sırbistan ve Memleketeyn emaretlerinin faydalandı̆̆ı haklar gibi imtiyazların verilmesini içerir şekilde yorumlanması mümkün olan bir kelimedir. Bosna-Hersek ve Bulgaristana özel imtiyazlar verilmesi politikaya gayet aykırı bir tedbirdir” demekteydi (Küçük, 1980: 132).

Oturumun devamında sefirler, Osmanlı Devleti'nin 2.ve 3. ret sebeplerinitartışmamışlardır. Netice olarak 4 Ocak 1877 tarihli görüşmeler de herhangi bir neticeye varılmadan sona ermiştir.

\section{MÜZAKERELERDE “BULGARISTAN” ADI ETRAFINDAKİ TARTIŞMA}

8 Ocak 1877 tarihli altıncı oturumda Kont Corti öncelikle, henüz uygulamaya konmamış Kanun-1 Esasi’nin, İmparatorluğun acil çözüm bekleyen vilayetleri için garanti teşkil etmediğini, teminat olarak addedilemeyeceğini belirtmiştir. Ayrıca Konferans evvelinde mutabık olunan hususların dışına çıkılmadığını savunmuştur. Corti’nin sözleriyle “... Babıali ile Avrupa Devletleri bizzat İngiltere’nin mektubundaki programı temel alarak, Bosna ve Hersek'te olduğu gibi Bulgaristan'da da yerel ya da idari bir otonominin tesisi çalışmalarına başlamıştı”.

Bu bağlamda idari taksimatla amaç, Avrupa Türkiyesi’nin durumu iyileştirilmesi gereken nüfusunu “...birleştirerek gruplamaktı". Bulgar nüfusunun çoğunlukta olacağı idari birimlerin teşkiliyle bu nüfusu, Müslüman ve Rumlar ile karşı karşıya gelmekten alıkoyup üzücü olayların tekrarının önleneceği düşünülmüştü.

Corti’nin sözleriyle önerilerinde sefirler İslimiye ve Filibe sancakları ile birkaç kazayı Edirne Vilayetinden, bazı kazaları da Selanik ve Manastır Vilayetlerinden ayırmakla, buralarda yeni âdem-i merkezi düzenin tesisini kolaylaştırma maksadını takip etmişti. Kont Corti’ye göre Hıristiyan ve Müslüman tebaayı olabildiğince ayrıştırmanın, Osmanlı İmparatorluğu’nun özel koşulları bağlamında gerekli ve işlevsel bir tedbir olduğu tartışılamazdı. Önerilen idari taksimatta Rum asıllı nüfusun da bulunacağı ve bunun ileride anlaşmazlık çıkmasına sebep oluşturacağı savı yersizdi. Zira sefirler öncelikle Bulgar tebaayı aynı idari birimde birleștirmek niyetindeydi. Bu bağlamda, din ve ibadet ayrımı olmaksızın ilgili yerleşimlerdeki Rumların tüm tebaayla aynı haklara sahip olacağını hatırlatmak yeterliydi. Kaldı ki sefirlere göre, nahiye düzeyinde tesis edilecek otonomiyle milletler arası aleyhtarlık kaybolmaya yüz tutacaktı.

Corti konuşmasını, Babıali ile Avrupa Devletleri arasındaki münasebetlerin gelecekte alacağı halin, bu Konferansın neticesine bağlı olacağı sözleriyle tamamlamıștır.

Ardından Lord Salisbury, Avrupa Devletleri'nin sadece ıslahat yapılmasını değil, garantilerin sunulmasını da talep ettiğini söylemiştir. Bosna, Hersek ve Bulgaristan için düşünülen yeni düzenlemeler, tebaaya kendi mahallerindeki işleri denetleme imkânı 
da sağlamalıydı. Onun sözleriyle, yeni idari sınırlar, Bulgaristan'da tebaaya verilmesi istenen garantiler bağlamında gerekli görülmüştü (BOA, HR.SYS. 1289/1-76-81). Böylece Salisbury Konferansa davet mektubunda bahsedilen, Bulgar nüfus için garantiler sağlama tavsiyesini kolaylıkla, idari taksimatla bağdaştırmıştır.

Konuşmasının devamında Salisbury projenin başlığındaki "Bulgaristan” adının, coğrafi sınırları çizilmiş olan bir bölgeyi işaret etmediğini belirtmiştir. Onun sözleriyle sefirler, kelime kökünü ve hâlihazırda yaygın anlamını göz önünde bulundurarak pratik bir manada yorumladıkları bu tabiri, Bulgar nüfusun yoğun olduğu ve geçen yaz isyanların vuku bulduğu bölgelere işaret etmede kullanmışlardı. Nitekim sefirler Edirne, Selanik ve Prizren Vilayetlerinin büyük bir kısmı için reform önermiyordu. Bu bağlamda sefirleri yeni “...sınır çizgileri..." (demarcation lines) belirlemeye yönelten iki husus, 1- nüfus yoğunluğu ve 2- isyanın çıtı̆̆ı bölgenin kapsanması gereği olmuştu. Bu ölçütleri gözettiklerinden dolayı “...Bulgaristan’n parçası olmayan...” bölgeleri mevzuya dahil etmeyecek bir isimlendirme seçmişlerdi (BOA, HR.SYS. 1289/1-76-81).

Cevaben Safvet Paşa Babıali’nin kabul edemeyeceği idari taksimat mevzuu bağlamında İngiltere'nin Konferans evvelindeki tavsiyeleri dışına çıkıldığını yinelemiştir. Lord Salisbury İngiltere'nin mektubunda "Bulgaristan" adını andıklarını, bundan dolayı Konferansın Bulgaristan’la özel olarak ilgilenmesi gerektiğini belirtmiştir. Safvet Paşa Osmanlı devlet ricalinin "Bulgaristan” adıyla genellikle Tuna Vilayetini algıladığı yanıtını vermiştir. Onun sözleriyle Babıali bu sebeple, İngiltere’nin davet mektubundaki önerilerin henüz kabul edilmediği sırada, burada geçen "Bulgaristan” kelimesini önemsememişti. Aynı sebeple Konferansın toplanmasını kabul ederken "Bulgaristan" tabiri ile ne demek istendiğini soramamıştı.

Safvet Paşa’nın bu sözlerine cevaben Rus, Alman ve İngiliz elçiler Konferansı toplama sebebinin Tuna Vilayeti dışında meydana gelen isyanlar olduğunu belirtmiştir. Önerdikleri reform Balkan dağının güney yamacındaki bölgelere yönelikti. Ancak öneriyi hazırlama aşamasında Tuna, Sofya, Prizren, Manastır, Edirne ve Selânik Vilayetlerinin tamamını ya da bir kısmını kapsama alma gereğini duymuşlardı (BOA, HR.SYS. 1289/1-76-81). Fakat bu sözleriyle sefirler dolaylı olarak, meselenin "Bulgaristan" ile ilgili olmadığını beyan etmekteydi.

Nitekim Osmanlı delegeleri bu bağlamda, belirli bir bölge yerine belirli bir nüfusa odaklanmanın yani, idari taksimatta değişiklik yapmaktansa evvela son olaylarda mağdur olan nüfusun durumunu iyileştirecek düzenlemeleri görüşmenin makul olacağını belirtmiştir. Onlara göre bu bir kez sağlandığında, ıslahatların çemberi tüm Avrupa Türkiyesi’ni kapsayacak şekilde genişletilebilirdi (BOA, HR.SYS. 1289/1-76-81). Fakat Salisbury’nin az evvel andığı 2. hususla (isyanın çıtı̆̆ı bölgenin kapsanması) aynı doğrultuda olan bu öneri sefirler tarafından dikkate alınmamıştır. Altıncı oturumun devamında gündem dağınık seyretmiş ve yine bir neticeye varılamamıştır.

Müzakerelerin üçüncü haftasına gelinmişken Sırbistan, Karadağ, Bosna, Hersek, yabancı 
denetleme komisyonu, âdem-i merkezileşme, hukuki düzenlemeler vs. meseleleri henüz etraflıca görüşülmemişti. İki Bulgaristan Vilayeti tesisi mevzusunda ise ısrarlı davrandıkları halde Avrupa Devletleri yeterli gerekçeler sunamamıştı.

\section{KONFERANSIN NETICESIZZ SONLANMASI}

11 Ocak 1877 tarihli yedinci oturumda Kont Zichy Osmanlı Devleti’nin idari bölgelerini adlandırma tarihçesinden bahisle önceki oturumda tartışılan "Bulgaristan” adı konusuna dönmüştür. Zichy Bosna örneğinde, fethedildiği dönemden bu yana Boşnak nüfusun yoğun bulunduğu bölgenin bu nüfusun adıyla yani, "Bosna” olarak anıldığını ve bir Vali tarafından idare edilmesiyle müstakil bir idari birim oluşturduğuna değinmiştir.

Onun sözleriyle, Rumların yoğun olduğu Epir, Makedonya, Tesalya da "Rumeli (Rumların ülkesi)" olarak adlandırılıyor, bir Valiyle idare ediliyordu. Karma nüfusun yaşadığı bölgeler ise buradaki en büyük ya da merkezi şehrin adını taşıyor ve aynı şekilde müstakil bir idari birimdi. Zichy’ye göre tarihsel açıdan Bulgaristan için de aynı olgu söz konusuydu: Bulgar nüfusun yoğun olduğu bölge bu nüfusun adıyla anılıyor ve bir Vali ile yönetiliyordu. Onun ifadesiyle, nitekim II. Mahmud döneminde yapılan idari değişiklik ile eski Bulgaristan yerine Tuna, Niş ve Sofya Vilayetleri kurulmuştu.

Zichy'ye cevaben Safvet Paşa Osmanlı Devleti’nin bir vilayeti olarak, yalnızca Bosna’nın eski adını koruduğunu belirtmiştir. Rumeli'nin diğer eyaletlerinde idari yapı çok kez değişmişti. Osmanlı toprağı olalı ise Bulgaristan şimdiye kadar vilayet olmamıştı. Safvet Paşa’nın sözleriyle Eksarhlığın kuruluşuna değin "Bulgaristan” adı, Babıali’nin hiçbir resmî evrakında yer almamıştı. Hâlihazırdaki idari yapı ise (Tuna Vilayeti) Osmanlı Devleti’nce en elverişli düzenleme olarak düşünülmüştü (BOA, HR.SYS. 1289/1-94-97). Ancak Safvet Paşa’nın bu savunması da dikkate alınmayarak müzakerenin konusu tekrar değişmiş, devamdaki konuşmalar dağınık seyredip yedinci oturum da neticesiz sonuçlanmıştır.

Tersane Konferansı'nın 15 Ocak 1877'de yapılan sekizinci oturumunda Lord Salisbury şimdiye kadar müzakerelerde çözüm yönünde ilerleme kaydedilemediğini, sundukları reform tavsiyelerini prensipte reddeden Babıali’nin tebaası için garantiler önermediğini ileri sürmüştür. Ona göre müzakereler, Osmanlı temsilcilerinin gayrı-yapıcı tutumu sebebiyle beyhude uzamıştı. Salisbury’nin sözleriyle, tartışmalara bir son verilmesi düşüncesiyle sefirler en nihayet, ilk önerilerinin hafifletilmiş bir özetini hazırlamıştı. Osmanlı Devleti bu son öneriye, 18 Ocak 1877'de yapılacak dokuzuncu oturumda kesin bir cevap vermeliydi. Nitekim Babıali buna da itiraz ettiği takdirde sefirler devletlerinden, İstanbul'dan ayrılma talimatı almıştı.

Mevzubahis hafifletilmiş öneride "Bosna, Hersek ve Bulgaristan" tek başlık altında toplanmıştı. Buna göre vilayetler, sancaklara ve 5.000-10.000 nüfuslu nahiyelere (müdürlüklere) taksim edilmeliydi. Sancaklar sabit süreyle, Valilerin tavsiye edeceği ve 
Babıali'nin tayin edeceği mutasarrıflarca yönetilmeliydi. Nahiyelerde her köyün ahalisince seçilecek kişiler yetkili kılınmalıydı vd. (BOA, HR.SYS. 1289/1-98-100). Bu kez iki yeni vilayetin kurulması önerilmiyordu. Dolayısıyla Bulgaristan meselesi, Osmanlı Devleti'nin vereceği nihai karardan hariç bırakılmış oluyordu. Öte yandan sefirler Vali tayini ve milletlerarası bir komisyonun kurulması tavsiyelerinde ısrar etmekteydi.

Bu konuşmaların ardından Safvet Paşa Babıali’nin daha ikinci oturumda bir karşı-öneride bulunduğunu fakat Avrupa Devletleri’nin buna hakkıyla ilgi göstermediğini belirtmiştir. Osmanlı tarafı olarak, Vali tayini ve milletlerarası bir komisyonun kurulması yönündeki iki talebin son öneriden çıkarılması halinde görüşmelere devam edeceklerini söylemiştir. Aksi halde Osmanlı Hükümeti, nihai bir karara varmak üzere olağanüstü bir Şûra toplayacaktı. Olumsuz yanıt alan Safvet Paşa süre istemiş, Babıali’nin son cevabını 20 Ocak 1877’ye ertelenen oturumda vermesi kararlaştırılmıştır (BOA, HR.SYS. 1289/1-98-100).

Tersane Konferansının dokuzuncu ve son oturumunda Osmanlı temsilcileri, toplanan olağanüstü Şûranın kararını (Uzunçarşılı, 1954: 123-133) tebliğ etmiştir: 1856 Paris Muahedesi ile Osmanlı Devleti’nin korunacağı garanti edilen bağımsızlığına aykırı düştüğü gerekçesiyle, Rumeli’de yabancı bir komisyonun teşkiline izin verilemeyeceği kanaatine varılmıştı. Bundan dolayı sefirlerin ikinci (son) önerisi de Devlet-i Aliyye tarafından reddedilmekteydi.

Safvet Paşa’nın devamdaki sözleriyle, coğrafî yakınlık dolayısıyla Rumeli vilayetleri Babıali tarafından doğrudan yönetilebilir ve denetlenebilirdi. Osmanlı Hükümetínin yürütebileceği bu görevlerin yerine getirilmesi amacıyla anılan bölgede Vali tayin usulünün değişmesi ve milletlerarası komisyonun kurulması zaruri değildi. Bu iki hususta sefirlerin ısrarı için sebep bulunmuyordu. Kaldı ki Osmanlı Devleti için büyük önem taşıyan Rumeli vilayetlerinin idaresi ve denetimi bağlamında dış müdahale kabul edilemezdi.

Konuşmasının sonlarında Safvet Paşa, Osmanlı Hükümeti'nin uzlaşmayı fevkalade arzu ettiğini yinelemiştir. Lord Salisbury ise Babıali’nin hâlâ vaatlerde bulunduğunu söylemiştir. Ardından son birkaç beyanı takiben sefirler, tartışmanın son bulduğuna karar vererek oturum kapatılmıştır (BOA, HR.SYS. 1289/1-109-111). Bir neticeye varılamayan, hiçbir konuda bağlayıcı karar alınmayan, herhangi bir akit imza edilmeyen İstanbul Konferansı böylece sona ermiştir. Sefirler yerlerine birer maslahatgüzar bırakarak İstanbul'dan ayrılmıştır (Küçük, 1988: 217).

\section{SONUÇ}

1876 İstanbul Konferansı neticesiz, alınmış ve tasdik edilmiş bir karar olmaksızın sona ermiştir. Bu toplantıda herhangi bir kararın alınmayışı Rusya’nın, Osmanlı Devleti’ne harp ilanı gerekçesi ve aylar evvel başlattığı askeri seferberliği savaşa vardırma vesilesi olmuştur. 
Yukarıda örneği verildiği üzere bazı kaynaklarda, Konferans'ta birtakım kararlar alındığı ya da Avrupa Devletleri’nin 11-22 Aralık 1876'daki ön görüşmelerde oluşturdukları ve İstanbul Konferansı'nın ilk oturumunda Osmanlı Devleti'ne sundukları projelerin karar niteliği taşıdığı yönünde yorumlanabilecek ifadelere rastlanmaktadır. Tarihsel süreci olduğu gibi yansıtmayan böyle ifadelerden dolayı konuyla ilgili yazında, Konferans protokollerinin Fransızca kaydedilmiş öneri başlıklarındaki "Projet" (Tr.: proje, tasarı, öneri, taslak) kelimesi göz önünde bulundurulmalıdır. Nitekim dönemin tanığı olan Mahmud Celâleddin Paşa kitabında, sefirlerce sunulan önerileri "Layiha" olarak da anmıştır (Celâleddin Paşa, 1326: 226).

Öte yandan Avusturya-Macaristan ile Rusya arasında yalnızca altı ay arayla yapılan Reichstadt ve Budapeşte görüşmeleri Avrupa Devletleri’nin, Tersane Konferansı öncesinde olduğu gibi sonrasında da geçici uzlaşılar sağlayabildiklerini gösteriyordu. Nitekim 93 Harbini takiben 1878'deki Ayastefanos müzakereleri, 1876 İstanbul Konferansı'nda görüşülen konulara atıfla yürütüldüyse de bunların sonucunda hazırlanan Ayastefanos Anlaşması, Avrupa Devletleri’nce tanınmamıştı. 1878 Berlin Konferansı'nda özelde Bulgar meselesi ve idari taksimat bağlamında kabul edilen hususların, İstanbul Konferansı̉na sunulan öneride yer alanlardan farklı olması da 1876'daki uzlaşıların geçiciliğini teyit etmişti.

İstanbul Konferansı tutanaklarını Bulgarcaya çevirerek 1885’te neşreden T. Ikonomov bunlara yazdığı önsözde, sefirlerin sunduğu öneriye göndermede bulunarak, bu toplantıda “...Avrupa tarafindan Bulgarların daha serbest bir hayat ve otonom idare haklarının yanı sıra vatanlarının, kendi (Bulgaristan) adını taşıma hakkının tanındığını..." söylemiştir. Zira yazarın sözleriyle Türkler, Bulgarların vatanını öz isminden mahrum etme niyetindeydi (1885, Protokolite na...: 3).

Genel kabul itibariyle, 1876 İstanbul Konferansỉna Bulgaristan konulu bir projenin sunulması, günümüz Bulgaristan ulus-devletinin tarih sahnesine çıkmasına yol açan gelişmelerden biri olmuştu. Bu çerçevede Osmanlı Devleti'nin bu projeye itirazı, yukarıda Ikonomov'dan alıntıladığımız ifadelerde adeta Bulgarlara herhangi bir hak tanımamasıyla bağdaştırılabilmektedir. Benzer bir anlamlandırmaya 1969 tarihli Kratka Balgarska Entsiklopediya kaynağında da rastlanmaktadır. Öte yandan Stoyanov'un satırlarına göre Babıali, Bulgar ulus-devletinin sınırlarını daha Eksarhlığın kuruluşuyla onaylamıştı. Ancak ilgili tarihsel süreci Konferans tutanaklarından ve özelde Osmanlı temsilcilerinin sözlerinden günümüz gözüyle incelediğimizde, Babıali’nin söz konusu projeye haklı ve makul gerekçelerle itiraz ettiği ortaya çıkmaktadır. Bundan başka söz konusu itirazın, ilgili tarihsel dönemde Bulgar tebaanın aleyhinde olduğu söylemi tartışılırdır. Zira Osmanlı Devleti, genelde tüm tebaası ve özelde Bulgar tebaası için yeterli serbestiyi temin etme gayretindeydi. Konferansın birinci oturumunda Safvet Paşa bunu, Bulgar Eksarhlı̆̆ı'nın kuruluşunu hatırlatarak vurgulamıştı.

Devlet-i Aliyye 19. yy. itibariyle ülkede yerel bir idare düzeni tesis etme çabasındaydı. Ancak bu, öncelikle ihtiyaç duyulan bazı bölgeleri kapsayarak ve nispeten yavaş ilerleyen 
bir değişimdi. Zira 1807 Kabakçı İsyanına varan süreç, ivedi ve kapsamlı ıslahat yapmanın sakıncalarını göstermişti. Bu olaylarla ıslahatın merkezi otoriteyi güçlendirmekle mümkün olacağı anlaşılmıştı. O nedenle Osmanlı Devleti’nde reformların, ortaya çıkan buhranlara çözüm bulma doğrultusunda küçük çaplı tutularak adım adım gidilmesi düşüncesi ağır basmaktaydı (Ortaylı, 2000: 13-20; Acar, 2013: 20).

Tuna Vilayetinin teşekkülü Osmanlı Devleti’ndeki kademeli ıslahat sürecinin bir parçası olmakla beraber Kırım Harbi sonrasındaki stratejik gereksinimlerin de neticesiydi. Bu yeni idari yapılanma diğer eyaletlerde yapılacak ıslahatın örneği olarak düşünülmüş ayrıca tesisinde Fransa’nın departman düzenlemesinden örnek alınmıştı. Dolayısıyla Osmanlı Devleti, güvenliğini ve tebaasının huzurunu bir arada temine gayret ederken yerine göre Avrupa'nın tecrübesinden de faydalanmaktaydı (Şentürk, 1992: 169; Acar, 2013: 44, 51). Netice olarak, ülkenin devam eden reform süreci koşullarında Tuna Vilayetinde, tebaaya olumlu yansıyacak bir düzenin başarılması mümkündü.

Özetle, 1876'da Osmanlı Devleti (asayiş meseleleri sebebiyle sekteye uğradığı halde) yıllar evvel başlayan bir sslahat sürecini deneyimlemekteydi. Dolayısıyla Avrupa Devletleri İstanbul Konferansı'nda, hâlihazırda sslahat sürecinde olan bir ülkeye, sslahat önerileri sunmuştu. Oysa yakın zamanda idari reform yapılan bir coğrafyada yeni bir değişikliğe gerek bulunmuyordu. Bu çerçevede Osmanlı Hükümeti özellikle Bulgar meselesi bağlamındaki önerilere itirazında haklıydı. Safvet Paşa’nın dile getirdiği üzere sefirlerce tavsiye edilenlerin, tebaanın memnuniyetsizlik duyması ihtimalinden dolayı uygulanabilir olmadığı; kapsamlı ve ani idari değişiklik yerine yalnızca son asayiş sorunlarının zuhur ettiği bölgelerde yerel iyileştirmeler yapılarak bunların bilahare genişletilmesi yönündeki itiraz ve karşı-önerileri de makul ve yerinde savunmalardı.

Öte yandan Tuna Vilayetinin kuruluşu, bir savaş çıkması olasılı̆̆ında Tuna nehri (Vidin, Rusçuk, Silistre), Karadeniz kıyısı (Varna) ve Rumeli’nin sağ kolu üzerindeki (Şumnu) kalelerin, dolayısıyla Balkan sıradağları kuzeyinin emniyete alınması düşüncesinin de neticesiydi. Vilayetin kapsadığı bölgeyi denetleyebilmek, Balkan sıradağları güneyindeki sahanın, Ege Denizi sahillerinin ve özellikle İstanbul'un güvenliği bakımından önem arz etmekteydi (Acar, 2013: 51). Dolayısıyla Osmanlı devlet adamları, Avrupa Devletleri ve bilhassa İngiltere ile Rusya arasında uzun süredir rekabet meselesi olan (Kurat, 2011: 64 vd.) ve Tuna nehri ile Balkan sıradağları ekseninde ayrışan doğal ve stratejik coğrafyanın farkındalığıyla hareket etmeliydi.

Bu bakımdan Safvet Paşa'nın dile getirdiği, diğer Osmanlı vilayetlerine nazaran Rumeli topraklarının, Babıali’nin denetleyebileceği yakınlıkta olduğu ve Devlet-i Aliyye için büyük (askeri, stratejik, iktisadi vd.) önem arz ettiği hususları, sefirlerin önerilerine itirazda haklı gerekçelerdi. Osmanlı Devleti, stratejik ehemmiyeti olan bu bölgeyi hâkimiyetinde bulunduramama olasılığını kabul edemezdi. Bu sebeple anılan coğrafyada, yeni idari taksimat bir yana, burada görev yapacak Valinin tayini ile yabancı bir komisyonun denetimine müsaade edilmesi düşünülemezdi. Neticede Babıali’nin sefirlere itiraz gerekçeleri keyfi ve tebaasının serbestisini kısıtlama maksatlı olmayıp, haklı sebeplere 
dayanmaktayd 1.

Kitab-ı Cihannüma'da "Memalik-i Rumeli” adıyla, genel olarak Balkan yarımadasına işaret edildiğini söylemek mümkündür (Kâtip Çelebi, 2008: 80-81). Osmanlıların Memalik-i Rumeli olarak, Avrupalıların ise Thracia, Macedonia, Moesia Inferior - Moesia Superior tarihi adlarıyla bildikleri coğrafya, 1820'lerin Avrupa haritalarında "La Turquie d'Europe (Avrupa Türkiyesi)" olarak gösterilmeye başlanmıştı. Avrupalıların tercih ettiği bu anma biçiminin Osmanlılarca da bir müddet sonra benimsendiği anlaşılmaktadır.

Konferans oturumlarında Balkanlar coğrafyasına işaret etmede, Osmanlı devlet ricali ile sefirlerin, "Avrupa Türkiyesi", "Balkanlar" ve "Rumeli" adlarını aynı anda ve eș anlamda kullandıklarını görüyoruz. Bu bakımdan konuşmalarda tek bir tabir kullanılmazken, algılanan ve bahsedilen coğrafya aynıdır. Öte yandan 18.-19. yy. Avrupa coğrafyacıları, hazırladıkları haritalarda "Bulgaristan" ve "Rumeli" adlarını coğrafi birer tabir olarak kullanmaktaydı (örn.: Lapie, 1827). Yukarıda Reichstadt görüşmeleri bağlamında değinildiği gibi Balkanların yüzey şekilleri dolayısıyla doğal olarak ayrışan "Bulgaristan" ve "Rumeli" coğrafyaları, Avrupa devlet ricalinin tasavvurunda da mevcuttu.

1803-1804'te İstanbul'da basılan ve Avrupa coğrafyacılarının eserleri örneğinde hazırlanan Cedid-i Atlas Tercümesi'nin Balkanlar ve Anadolu’yu gösteren haritasinda Tuna nehri ile Koca Balkan sıradağları arasındaki saha "Bulgaristan"; sıradağların güneyi ise "Rumeli" adıyla gösterilmekteydi (1218, Greece and Turkey). Bu bağlamda Osmanlı okurları, ilgili coğrafyayı anmada 19. yy.da Avrupalılarca kullanılan "Bulgaristan" ile "Rumeli" tabirlerine ve bağdaştırıldıkları coğrafyalara aşina olmalıydı.

Cedid-i Atlas Tercümesinnde "Bulgaristan" adıla gösterilen bölge, Osmanlı Devleti'nin 1803-1804’teki idari taksimatında, Rumeli Beylerbeyliği’nin Sofya ve Özü Eyaletlerine bağlı bazı sancakları kapsıyordu (İnciciyan ve Andreasyan, 1974, 1976). Eyalet ve sancakların zaman içerisinde yeniden düzenlenmesiyle Silistre, Vidin ve Niş Eyaletleri teşkil edilmiş ve en nihayet bunların 1864'te bileştirilmesiyle Tuna Vilayeti kurulmuştu (Şentürk, 1992: 169; Acar, 2013: 2). Dolayısıyla ilgili bölgeyi anmada kullanılan tarihi, coğrafi ve idari adlandırmalar tarihsel süreçte değişmekte ve zihinlerde bazen eski, bazen yeni adlarıyla yer etmekte, bazen de birbirine karışabilmekteydi. Bu bakımdan Safvet Paşa'nın altıncı oturumdaki, İngiltere’nin Konferansa çağrı mektubunda geçen "Bulgaristan" adının Osmanlı devlet ricalinin dikkatini çekmeyip Tuna Vilayetini işaret eder manada algılandığı yönündeki izahından kuşku duymak pek doğru olmayacaktır.

Bundan ötürü Konferans’ta "Bulgaristan” adı etrafındaki tartışma, yukarıdaki alıntılarda Ikonomov tarafindan ayrıca Kratka Balgarska Entsiklopediya’da ileri sürüldügü doğrultuda değerlendirilemez. Osmanlı devlet ricali "Bulgaristan" adlandırmasına pek muhtemel aşina olduğu halde ilgili coğrafyayı, o tarihteki idari tabirle yani, Tuna Vilayeti olarak anması doğaldı. Bu anma biçimini, Osmanlı Devleti’nin Bulgar tebaasının varlığını inkâr ettiği yönünde yorumlamak mümkün değildir. Nitekim Ikonomov'un eseri ve Kratka Balgarska Entsiklopediya'daki cümleler ile Stoyanov'un 2003'te yazdığ 1 satırlar, Bulgar 
TROYACADEMY

International Journal of Social Sciences

müelliflerinin zaman içerisinde ayrışmış, birbirinin zıddı olan ifadelerdir.

1876 İstanbul Konferansı'na Sunulan Doğu ve Batı Bulgaristan Vilayetleri Önerisi 


\section{KAYNAKÇA}

(1218) [1803-1804]. Greece and Turkey. Cedid Atlas Tercümesi. Haz. Raif, M., Faden, W., vd. İstanbul: Tab’hane-yi Hümayun. Erişim 8 Aralık 2019, https://www.loc.gov/ resource/g3200m.gct00235/?sp=48

(1885). Protokolite na Tsarigradskata Konferentsiya s Londonskiy Protokol. Çev. Ikonomov, T. Varna: Pechatnitsa L. Nitche.

(1895). Entsiklopedicheskiy Slovar' Brokgauza i Efrona. Vol. XVI. St. Peterburg: TipoLitografiya I. A. Efrona.

(1922a). Convention secrète entre la Russie et l'Autriche-Hongrie. Budapest 1877. Krasnyy Arhiv. Istoricheskiy Zhournal. 1, 50-60.

(1922b). Tekst Reyhshtadtskogo Soglasheniya. Krasnyy Arhiv. Istoricheskiy Zhournal. 1, 36-38.

(1969). Kratka Balgarska Entsiklopediya. T. 5. Sofia: Izdatelstvo na BAN.

(2019a). Constantinople Conference. Erişim 7 Kasım 2019, https://www.wikiowl.com/ enhttp:https:http:/wiki/Constantinople_Conference\#Notes

(2019b). Tersane Konferansı. Erişim 23 Kasım 2019, https://www.wikizero.com/tr/ Tersane_Konferans\%C4\%B1

Acar, K. (2013). Osmanlı Devletinde Bir İdârî Reform Denemesi: Tuna Vilâyeti (18641867). Doktora Tezi. Danışman: Prof. Dr. Necdet Hayta. Ankara: Gazi Üniversitesi Sosyal Bilimler Enstitüsü Tarih Anabilim Dalı Yakınçağ Tarihi Bilim Dalı.

Baltalı, K. (1987). 1875 Hersek Ayaklanmasının Uluslararası Bir Nitelik Kazanması. Belleten, LI (199), 205-230.

Baykal, B. S. (1941). Doksanüç Harbi Esnasında Muhtelif Tavassut ve Sulh Şayia ve Teşebbüsleri. Belleten, V (19), 351-395.

BOA, HR.SYS.1289/1-14-18.

BOA, HR.SYS.1289/1-147.

BOA, HR.SYS.1289/1-19-25.

BOA, HR.SYS.1289/1-29-32.

BOA, HR.SYS.1289/1-35-38. 
BOA, HR.SYS.1289/1-6.

BOA, HR.SYS.1289/1-76-81.

BOA, HR.SYS.1289/1-94-97.

BOA, HR.SYS.1289/1-98-100.

BOA. HR.SYS. 1289/1-109-111.

BOA. HR.SYS. 1289/1-181-182.

Celâleddin Paşa, M., (1326). Mirât-ı Hakîkat (Târih-î̀ Mahmud Celâleddin Paşa). Dersaadet: Matbaa-yı Osmaniye.

Celâleddin Paşa, M., (1983). Mirầt-ı Hakîkat (Târihî Hakîkatların Aynası). Yayına Haz.: İsmet Miroğlu. İstanbul: Berekât Yayınevi.

Gözübüyük, A. Ş. ve Kili, S. (1982). Türk Anayasa Metinleri 1839-1980. 2. Bs. Ankara: AÜSBF Yayını.

Grossmann, V. R. [1894]. Die Staaten der Balkan-Halbinsel. Neuer grosser Hand-Atlas. Berlin: Verlag von R. Grossmann, 33-34. Erişim 17 Kasım 2019, https://www.loc.gov/ resource/g3200m.gct00404/?sp=63\&clip $=1215,1886,3023,2302 \&$ ciw $=830 \&$ rot $=0$

Güllü, R. E. (2018). Bulgar Eksarhlığı’nın Kuruluşu ve Statüsü. Gaziantep Üniversitesi Sosyal Bilimler Dergisi, 17 (1), 350-361.

Harenberg, J. Ch. (1741). Imperii Tvrcici Evropaei terra in primis Graecia. [Nuremberg, Bavaria]:Curantibus Homannianis Heredibuscum privil.Erişim 17Kasım2019, https:// www.loc.gov/resource/g7430.fi000241/?clip=1946,1278,3208,2173\&ciw=1088\&rot=0

İnalcık, H. (1992). Tanzimat ve Bulgar Meselesi. İstanbul: Eren Yayınları.

İnciciyan, P. L. ve Andreasyan, H. D. (1974 ve 1976). Osmanlı Rumelisi Tarih ve Coğrafyası. Güney-Doğu Avrupa Araştırmaları Dergisi, 2-3, 11-88 ve 4-5, 101-152.

Kâtip Çelebi. (2008). Avrupa Kıtası (Haritası). Kitâb-ı Cihânnümâ, 360 Yıllık Bir Öykü. Haz., Özükan, B., Koloğlu, O., Kaçar, M., Öneş, M. 2. Bs. İstanbul: Boyut Yayıncılık.

Kiepert, H. (1855). General-Karte des Türkischen Reiches in Europa und Asien. Berlin: Verlag von Dietrich Reimer. Erişim 17 Kasım 2019, https://www.loc.gov/resource/ g7430.fi000154a/?clip $=2514,2390,3630,2380 \& \mathrm{ciw}=807 \& \mathrm{rot}=0$

Koyuncu, A. (1998). Bulgar Eksarhlığı. Yüksek Lisans Tezi. Danışman: Yrd. Doç. Dr. 
Ahmet Altıntaş. Çanakkale: Çanakkale Onsekiz Mart Üniversitesi Sosyal Bilimler Enstitüsü Yakınçağ Tarihi Ana Bilim Dalı.

Koyuncu, A. (2013). 1877-1878 Osmanl-Rus Harbi Öncesinde Şarkî Rumeli Nüfusu. Avrasya Etüdleri, 44 (2013-2), 177-208.

Kurat, A. N. (2011). Türkiye ve Rusya. XVIII. Yüzyıl Sonundan Kurtuluş Savaşına Kadar Türk-Rus İlişkileri (1798-1919). 2. Bs. Ankara: TTK Yayınları.

Küçük, C. (1980). Bulgar İhtilâli’nin (1876) İngiliz Kamuoyunda Uyandırdığı Tepki ve Bunun Osmanl1-İngiliz İlişkilerine Tesiri. Güney-Doğu Avrupa Araştırmaları Dergisi, 8-9, 117-166.

Küçük, C. (1988). II. Abdülhamid. İslâm Ansiklopedisi. C. 1. TDV İslâm Araştırmaları Merkezi (DİA) Yayını. Erişim 27 Ekim 2019, https://cdn.islamansiklopedisi.org.tr/ dosya/1/C01000270.pdf.

Lapie, M. P. (1827). Carte Générale de la Turquie d'Europe et de la Grèce. Paris: Chez C. Picquet in (1830). Atlas de Choix ou Recueil de Cartes de Geographie Ancienne et Moderne Dressées par nos Meilleurs Auteurs. Paris: Chez J. Andriveau-Goujon. David Rumsey Map Collection at Stanford University Libraries, 30. Erişim 8 Aralık 2019, https://searchworks.stanford.edu/view/11514034

Ortaylı, İ. (2000). Tanzimat Devrinde Osmanl Mahallî İdareleri (1840-1880). Ankara: TTK Yayınları.

Pribram, A. F. ve Coolidge, A. C. (1921). The Secret Treaties of Austria-Hungary, 18791914. V. II. Cambridge: Harvard University Press.

Rupp, G. (1925). The Reichstadt Agreement. The American Historical Review, 30 (3), 503 510. (Erişim: 7.11.2019), www.jstor.org/stable/1835578.

Stanford, E. (1886). The Eastern question in Europe and Asia Map. London: Edward Stanford Ltd. Erişim 17 Kasım 2019, https://www.loc.gov/resource/g7420. ct003773/?clip=351,2005,1571,1058\&ciw $=907 \&$ rot $=0$

Stoyanov, I. (2003a). Balgarskiyat vapros v evropeyskata politika prez 1876-1877 g. Istoriya na Balgariya 681-1944. v. I. Sofia: Sofi-R, 704-709.

Stoyanov, I. (2003b). Formirane na Balgarskata natsiya. Istoriya na Balgariya 681-1944. v. I. Sofia: Sofi-R, 622-629.

Şentürk, M. H. (1992). Osmanlı Devletinde Bulgar Meselesi (1850-1875). Ankara: TTK Yayınları. 
Uzunçarşılı, İ. H. (1954). Tersane Konferansının Mukarreratı Hakkında Şûra Mazbatası. Tarih Dergisi, VI (9), 123-133.

Wyld, J. (1856). Treaty map shewing the boundaries of Russia \& the Eastern European states. London: Published by James Wyld. Erişim 17 Kasım 2019, https://www.loc. gov/resource/g7001f.fi000094/?clip $=1554,3988,1864,1434 \& \mathrm{ciw}=855 \& \operatorname{rot}=0$ 
